\title{
The Early and Middle Neolithic in NW Russia: radiocarbon chronologies from the Sukhona and Onega regions
}

\author{
Henny Piezonka ${ }^{1}$, Nadezhda Nedomolkina 2 , Marina Ivanishcheva 3 , \\ Natalya Kosorukova 4, Marianna Kulkova 5 and John Meadows 6,7 \\ 1 Institute of Pre- and Protohistory, Christian Albrechts University Kiel, Kiel, DE \\ hpiezonka@ufg.uni-kiel.de \\ 2 Vologda State Museum for History, Architecture and Art, Vologda, RU \\ 3 Child and Youth Centre 'Lider', Vologda, RU \\ 4 Cherepovets State University and Cherepovets Museum Association, Cherepovets, RU \\ 5 Russian State Pedagogical University 'A. I. Herzen', Sankt-Peterburg, RU \\ 6 Centre for Baltic and Scandinavian Archaeology, Foundation of the Schleswig-Holstein State Museums Schloss \\ Gottorf, Schleswig, DE \\ 7 Leibniz Laboratory for Radiometric Dating and Stable Isotope Research, Christian Albrechts University Kiel, Kiel, DE
}

ABSTRACT - The onset of the Neolithic period in the Russian North is defined by the emergence of pottery vessels in the archaeological record. The ceramics produced by mobile hunter-gatherer-fisher groups in the north-eastern European forest zone are among the earliest in Europe, starting around 6000 cal BC. After the initial mosaic of local styles in the Early Neolithic, including sparsely decorated wares and early Comb Ware, the Middle Neolithic period, starting in the $5^{\text {th }}$ millennium cal BC, saw the development and spread of larger, more homogenous typological entities between the Urals and the Baltic, the Comb-Pit and PitComb wares. Absolute chronologies, however, are still subject to debate, due to a general lack of reliable contextual information. Direct ${ }^{14} \mathrm{C}$ dating of carbonised surface residues ('food crusts') on pots can help to address this problem, as it dates the use of the pottery; but if aquatic foods were processed in the vessels, the respective radiocarbon ages can appear to be too old due to the freshwater reservoir effect. In this paper, we discuss the radiocarbon chronologies of four important stratified archaeological complexes in the region between Lake Onega and the Sukhona basin, Berezovaya Slobodka, Veksa, Karavaikha, and Tudozero. A growing series of dates, including AMS dates, sheds new light on the onset and further periodisation of the Early and Middle Neolithic in this important area between Eastern Fennoscandia, Central Russia and the Far North-East of Europe, although problems concerning the absolute chronology of the initial Neolithic remain.

KEY WORDS - Northern Russia; hunter-gatherer-fishers; early pottery; Early and Middle Neolithic; radiocarbon chronology; stratigraphy; $7^{\text {th }}-5^{\text {th }}$ millennium cal BC

\section{Zgodnji in srednji neolitik v SZ Rusiji: radiokarbonske kronologije iz regij Sukhona in Onega}

IZVLEČEK - Začetek neolitika je na severu Rusije definiran s pojavom lončenih posod, ki so jih izdelovale mobilne skupine lovcev-nabiralcev-ribičev na območju gozdne cone na severovzhodu Evrope, in so ene najstarejših v Evropi, saj se pojavijo ok. 6000 pr. n. št. Po začetnem mozaiku lokalnih stilov v zgodnjem neolitiku, ki vključuje manj okrašene posode in zgodnjo glavničasto keramiko, sta se v srednjem neoliti$k u, z$ začetkom v 5. tisočletju pr. $n$. št., pričela razvoj in širitev večje in bolj homogene tipološke entitete med Uralom in Baltikom, t. i. skupine z vdolbinami in glavničastim okrasom na keramiki. Zaradi pomanjkanja zanesliivih podatkov o kontekstih je absolutna kronologija za ta čas še vedno stvar debate. Direktni ${ }^{14} \mathrm{C}$ datumi zoglenelih organskih ostankov hrane na površini posod so nam sicer v pomoč, saj neposredno datirajo uporabo teh posod; vendar so lahko datumi ostankov hrane (vodni organizmi) prestari zaradi učinka rezervoarja ogljika $v$ tekočih vodah. V članku razpravljamo o radiokarbonskih kronologijah štirih pomembnih arheoloških kompleksov v regiji med jezerom Onega in kotlino reke Sukhone; to so najdišc̆a Berezovaya Slobodka, Veksa, Karavaikha in Tudozero. Naraščajoče število datumov nam bolje osvetli začetek in nadaljnjo periodizacijo zgodnjega in srednjega neolitika na tem pomembnem območju med vzhodno Fenoskandijo, centralno Rusijo in severovzhodno Evropo, kljub temu da še vedno ostajajo težave, povezane z absolutno kronologijo začetnega neolitika.

KLJUČNE BESEDE - severna Rusija; lovci-nabiralci-ribiči; zgodnja lončenina; zgodnji in srednji neolitik; radiokarbonska kronologija; stratigrafija; 7.-5. tisočletje pr. $n$. št. 


\section{Introduction}

The onset of the Neolithic period in north-eastern Europe is defined by the emergence of pottery vessels in the archaeological record (Oshibkina 1996. 6; Chairkina, Kosinskaya 2009). This definition is rooted in the development of eastern European and Soviet scientific terminologies and differs from the understanding of the Neolithic period in western European archaeology, where the main criterion is the transition from a foraging to a productive economy with agriculture and/or animal husbandry (Oshibkina 2006; Piezonka 2017; Timofeev et al. 2004.8-11). In the north-east European forest zone, the pottery produced by mobile hunter-gathererfisher groups is among the earliest in Europe, probably appearing by the end of the $7^{\text {th }}$ millennium cal $\mathrm{BC}$ in the Upper Volga region of central Russia and possibly even earlier in the Dvina-Lovat' interfluve in western Russia (Hartz et al. 2012; Mazurkevich, Dolbunova 2015). The earliest ceramic vessels in this region appeared in a cultural environment based on a foraging economy and seasonal mobility. In most parts of the forest zone of north-eastern Europe, the hunter-gatherer-fisher lifestyle continued also in the Middle and Late Neolithic and into the Early Metal Age.

Stratigraphic observations and the typological evolution of pottery styles and lithic industries provide the main tools for building relative archaeological chronologies of the Neolithic. On this basis, regional sequences of cultural units have been worked out in more or less detail for various parts of north-eastern Europe (for overviews, see $\mathrm{Ma}$ zurkevich, Dolbunova 2015; Piezonka 2015). Absolute chronologies, however, are still subject to debate, due to a general lack of dependable dates and reliable contextual information. Therefore, one of the foremost tasks in current research is to build reliable chronological frameworks for the emergence and further evolution of early ceramics and their cultural contexts. An important step was taken recently with the publication of an edited volume summarising the current state of knowledge of radiocarbon chronologies for European Russia (Zaitseva et al. 2016)

Until relatively recently, the absolute chronology of the appearance and evolution of early pottery in this region and thus of the development of the Neolithic was largely based on radiometric ${ }^{14} \mathrm{C}$ measurements, often with large uncertainties, from samples such as charcoal, wood, and organic sediment, found in more or less reliable association with the pottery concerned. In recent years, AMS ${ }^{14} \mathrm{C}$ dating of carbonised food crusts on pottery has become widespread, as it provides dates directly associated with the various types of pottery that are typologically relevant for understanding cultural developments (Piezonka 2008). However, this method compels us to confront another problem: that carbon in freshwater food chains is often subject to large and variable freshwater reservoir effects (FRE). So if fish were cooked in pots, some ${ }^{14} \mathrm{C}$-depleted carbon is likely to have been incorporated into food crusts, causing dating results that can be too old compared to the actual age of the dated samples (Fischer, Heinemeier 2003; Heron, Craig 2015; Piezonka et al. 2016). This question is addressed in various ways: 1) discrepancies between calibrated ${ }^{14} \mathrm{C}$ ages and the relative chronology of the samples based on archaeological information; 2) paired samples of different materials; 3 ) the percentage of carbon in each sample derived from aquatic sources under certain cir-

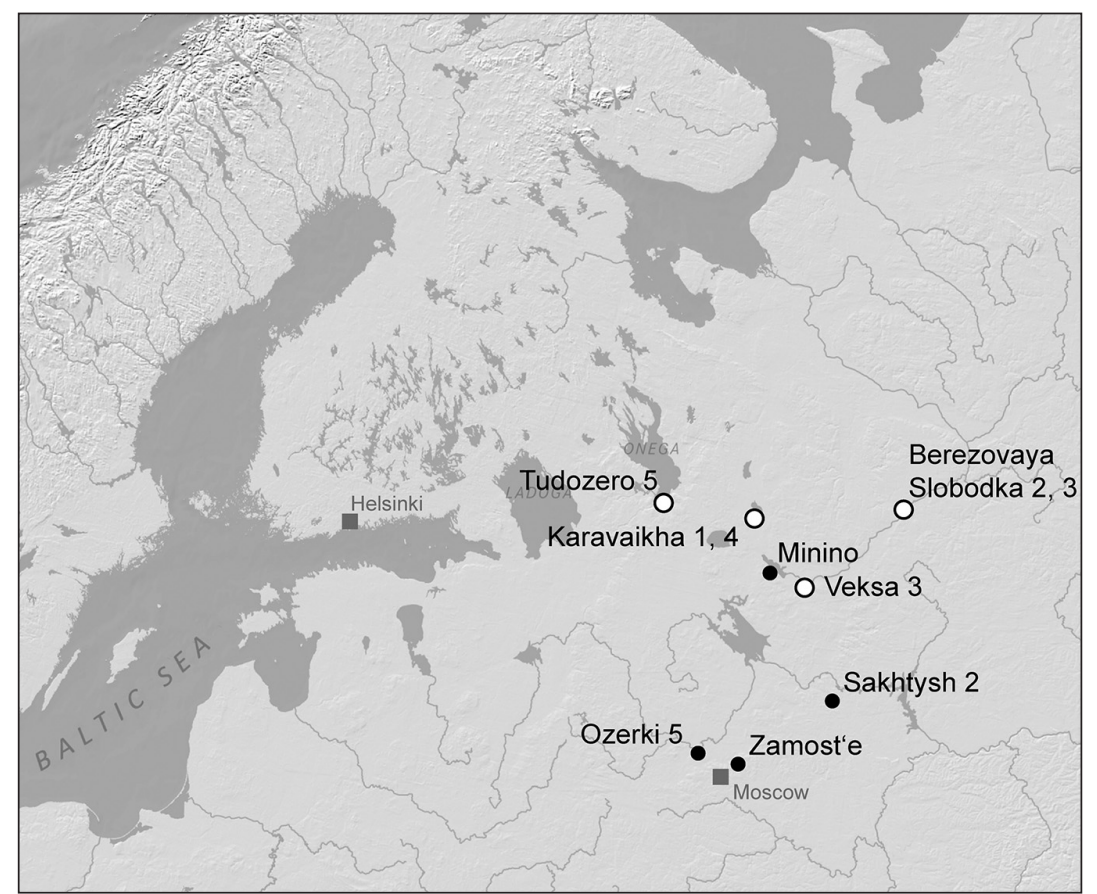

Fig. 1. Sites in north-eastern Europe with radiocarbon dated Early and Middle Neolithic pottery complexes discussed in the text (white dots) and other sites mentioned (black dots). 
cumstances can be estimated from Elemental Analysis-Isotope Ratio Mass Spectrometry results; 4) qualitative and semi-quantitative analytical techniques (microscopy and biomolecular analyses) may be used to attribute components of food crusts to terrestrial or aquatic sources.

In this paper, we discuss the radiocarbon chronologies for Early and Middle Neolithic complexes of four key sites in northern Russia: Berezovaya Slobodka in the Middle Sukhona region, the stratified complexes of Veksa 1 and 3 in the Upper Sukhona basin, the sites of Karavaikha 1 and 4 in the Lake Vozhe basin, and the stratified dune site of Tudozero 5 on the southern shore of Lake Onega (Fig. 1). This area is an important intermediate region, because the Baltic, Polar, and Caspian hydrological basins are divided here by the Main European Watershed. This makes the area central for understanding cultural links, trajectories and developments in the later Stone Age between Eastern Fennoscandia, Central Russia and the Far North-East of Europe up to the Polar Urals and the Barents Sea.

Early and Middle Neolithic complexes of the Sukhona and Onega regions

\section{Sukhona basin}

The River Sukhona is one of the larger rivers in Northern Russia. Rising in Lake Kubena, it runs $558 \mathrm{~km}$ north-east before flowing into the Malaya Severnaya Dvina. The Sukhona basin is part of the Barents Sea drainage system, although through short passages across watersheds, it is also closely connected to the Volga basin to the south, which is part of the drainage area of the Caspian Sea (Fig. 1). In terms of geomorphology, the Sukhona basin can be divided into upper, middle and lower parts. The upper and middle portions are linked by tributaries of River Kostroma to the upper Volga region, while the lower course of the Sukhona is connected via the River Jug to the middle Volga, Kama and Urals regions. Thus the Sukhona basin is an important contact zone in North-Eastern Europe, connecting the environmental and cultural spheres of the Baltic, the Volga and the Urals. In this paper, two archaeological complexes which are pivotal for the study of the Neolithic in this region are discussed, Berezovaya Slobodka by the lower course of the Sukhona, and Veksa in the Upper Sukhona basin.

\section{Berezovaya Slobodka II-III, VI}

The archaeological sites of Berezovaya Slobodka IIIII and VI are located on the bank of the lower Sukhona in the Nyuksensky district of Vologda region (Fig. 1). The Neolithic settlement of Berezovaya Slobodka VI is situated around $1 \mathrm{~km}$ upstream from the stratified multi-period complex of Berezovaya Slobodka II-III. The first archaeological finds were made close to the village of Berezovaya Slobodka by Myk-

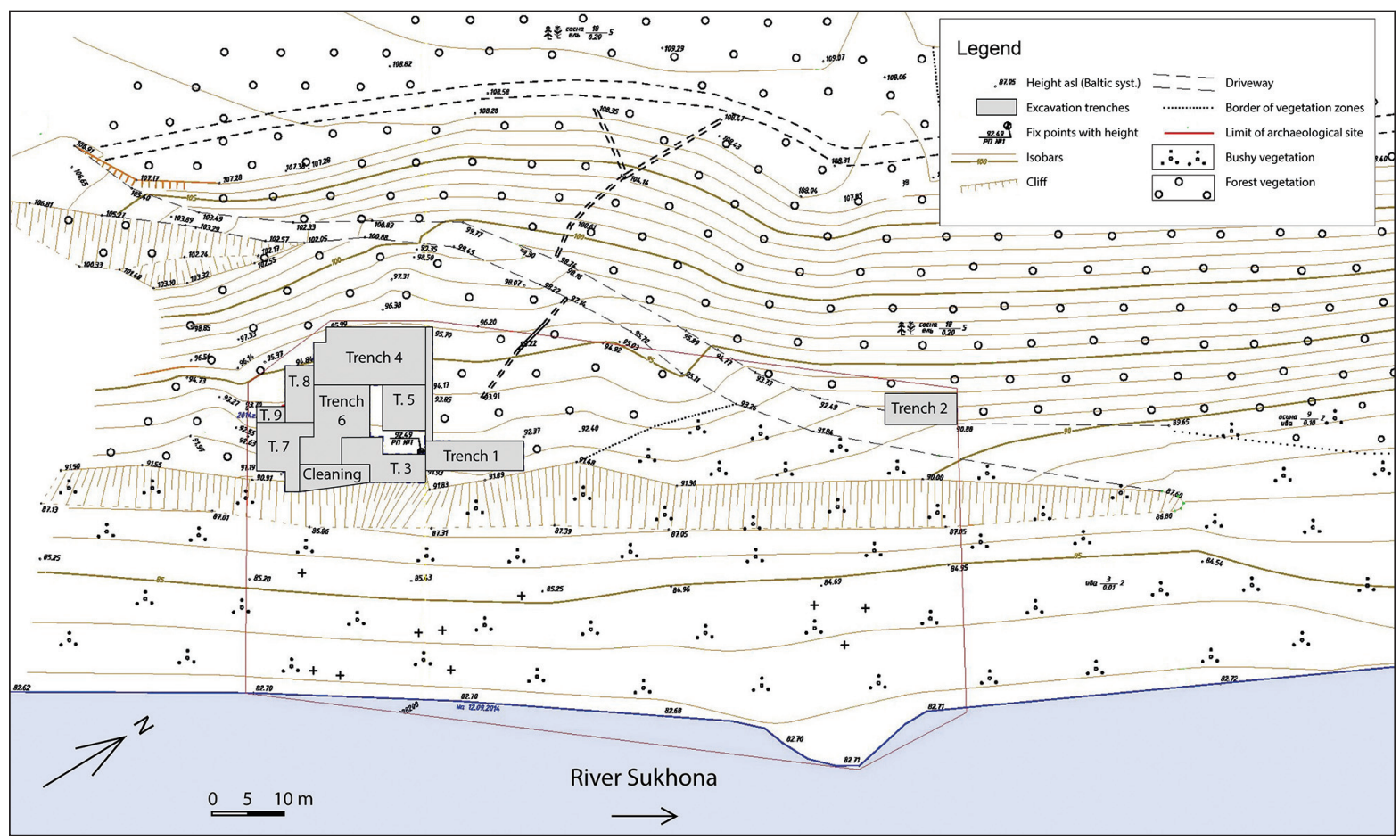

Fig. 2. Berezovaya Slobodka II-III, Vologda province, Russia. Excavated area on the north bank of the River Sukhona (designed by M. Ivanishcheva, based on a survey completed by V. A. Lobanov in 2014). 


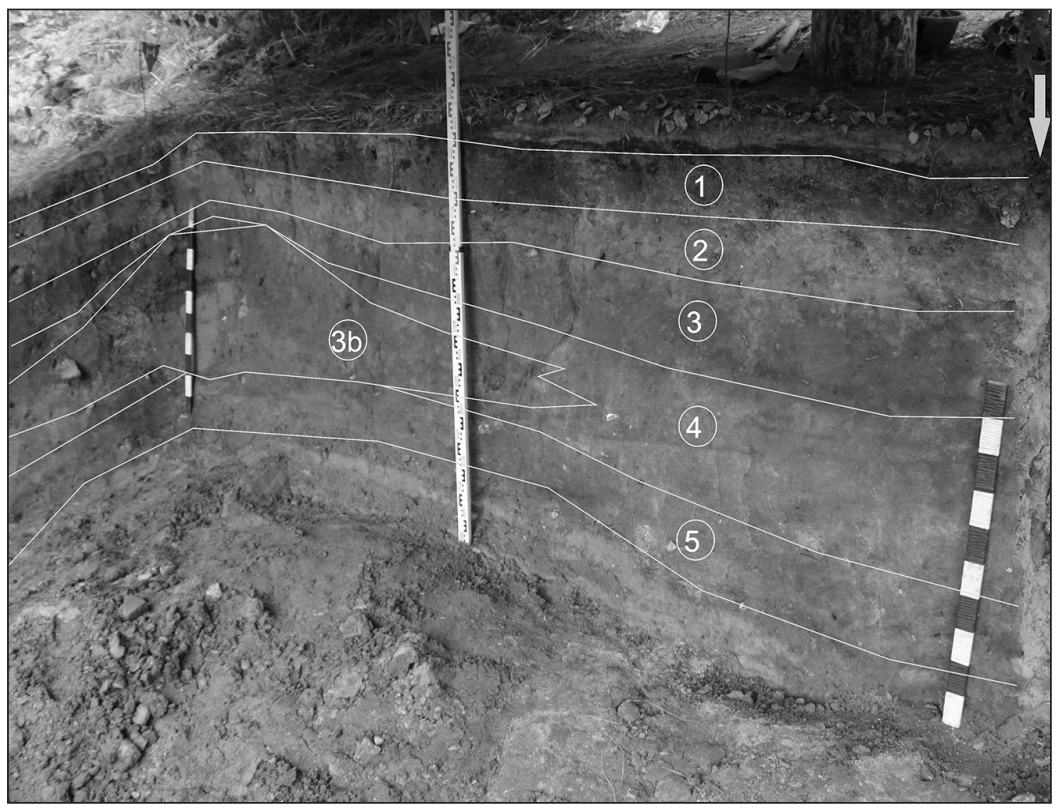

Fig. 3. Berezovaya Slobodka II-III, Vologda province, Russia. Stratigraphy of trench 9 of 2014 in the south-western part of the site: 1 topsoil; 2 cultural layer of the Bronze Age and Eneolithic; 3 Early Neolithic cultural layer; $3 b$ layer with relocated materials of the Final Palaeolithic; 4 sterile horizon; 5 Mesolithic cultural layer; 6 subsoil (designed by M. Ivanishcheva).

haylo Ya. Rudinsky in 1941. In 1977, the Moscow archaeologist and Stone Age specialist Svetlana V. Oshibkina documented a Mesolithic settlement site in the centre of the village on the left bank of River Uftyuga. Since 1995, Marina V. Ivanishcheva and her team have discovered and investigated numerous archaeological sites on the right bank of the river, among them the Berezovaya Slobodka IV, V and IX Mesolithic sites, the Berezovaya Slobodka VI Neolithic site, the Early Iron Age settlement of Berezovaya Slobodka I, and the multiperiod site of Berezovaya Slobodka II-III, with evidence from the Late Palaeolithic to the Early Iron Age (Ivanishcheva, Ivanishchev 2006).

\section{Archaeological background of Berezovaya Slobod-} ka II-III

The Berezovaya Slobodka II-III site occupies the slope of the river terrace between 8 and $13 \mathrm{~m}$ above the water level. Altogether covering some $4800 \mathrm{~m}^{2}$, a total of $507 \mathrm{~m}^{2}$ of its southern part has been excavated (Fig. 2). The stratigraphy of cultural layers amounts to $1.7-2.2 \mathrm{~m}$ in thickness, and encompasses material from the Mesolithic to the Bronze Age and in places to the Iron Age (Fig. 3). The upper part of the stratigraphy comprises silty sediments up to $0.7 \mathrm{~m}$ thick, while the lower part features clayey soils and clays up to $1.5 \mathrm{~m}$ thick. The Early Neolithic horizon consists of dark grey silts up to $0.6 \mathrm{~m}$ thick. It occupies an area of some $400 \mathrm{~m}^{2}$ and is covered by sediments with archaeological material from later periods. In the Early Neolithic horizon, successive occupations over a considerable time span are indicated by the various pottery types, including undecorated, pricked, and combimpressed wares. To date, the ceramic collection comprises a minimum of 21 vessels with either no decoration or pricked decoration (Fig. 4), three to five vessels with comb decoration (Ivanishcheva 2006.91, Fig. 7), and eight to ten vessels with a specific comb-pitted decoration that is associated with the later phase of the Early Neolithic (Nedomolkina, Ivanishcheva 2014. 16, Fig. 3).

In the area close to the river, two separate layers can be distinguished within the Early Neolithic horizon, separated by a sterile band. The lower layer has revealed several hearths and fireplaces, as well as ceramic fragments and other finds. The pottery includes fragments of three to four vessels with thin walls, polished surfaces and bands of small round impressions below the rim. The vessels measure up to $20 \mathrm{~cm}$ in diameter and have a low flowerpot-like shape, with broad flat bases. One base bears radial ornamentation formed by small triangular impressions. The fabric is either tempered with grog and organics or contains no artificial temper.

\section{Dated samples and results}

The absolute chronology of the lower Early Neolithic layer is based on two radiocarbon dates (Fig. 5; Tab. 1). One stems from a fireplace (Le- $6713,7340 \pm 200$ $\mathrm{BP})$, and one from a hearth beside which the abovementioned decorated pottery base was found (Le$6707,7340 \pm 90$ BP) (Ivanishcheva 2009.278-279). Falling in the second half of the $7^{\text {th }}$ and the beginning of the $6^{\text {th }}$ millennium cal $\mathrm{BC}$, these two dates are among the oldest for a pottery-bearing complex in the Northeast European forest zone.

In the upper layer of the Early Neolithic horizon at Berezovaya Slobodka II-III, excavations revealed the remains of a rectangular sunken-floor house with two hearths and an associated domestic pit (Ivani- 

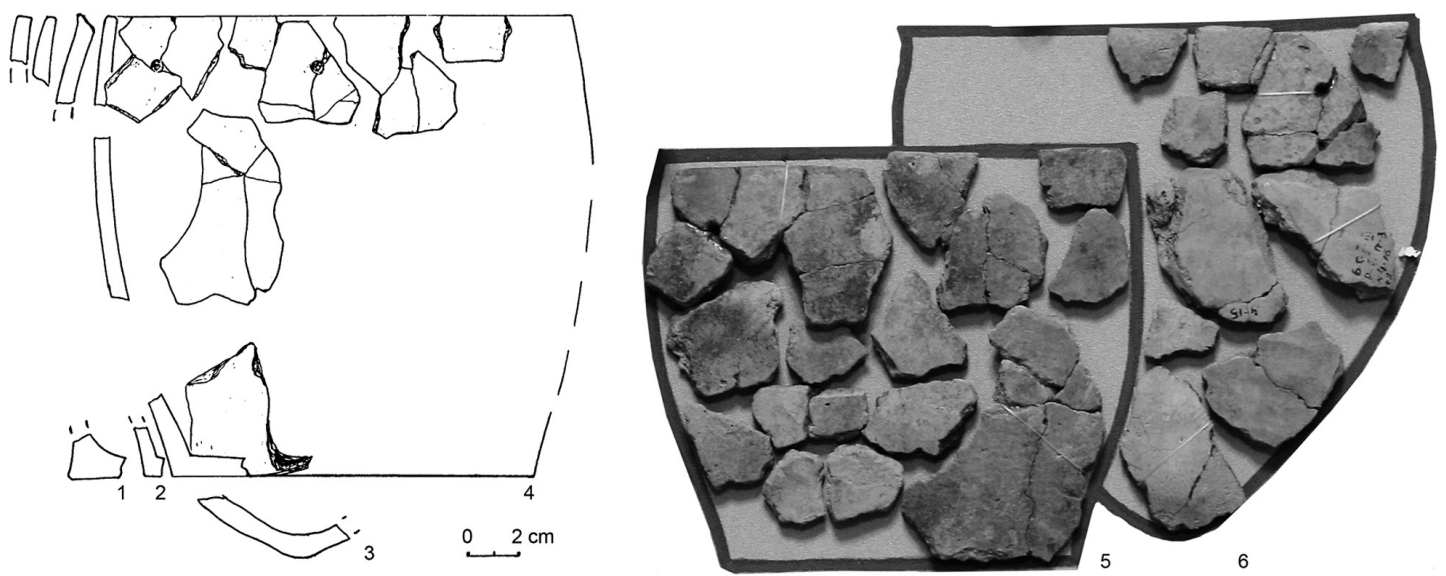

Fig. 4. Berezovaya Slobodka II-III, Vologda province, Russia. Undecorated pottery from Early Neolithic layer 1. 1-4 graphic reconstruction of pottery from a ceramic concentration in the corner of a house pit and from a nearby household pit; 5 fragments of one vessel from the household pit; 6 fragments of one vessel from the household pit and two vessels from the pottery concentration. Radiocarbon date from one flat-based vessel from the pottery concentration: Ki-16392a (designed by M. Ivanishcheva).

shcheva 2006.88-89, Fig. 1). In the infill of the house pit, fragments were found of at least three flat-based, flowerpot-shaped ceramic vessels, decorated with small pitted or dot-like impressions (Ivanishcheva 2006.95, Fig. 2-1). Fragments of four to five undecorated vessels with polished surfaces, among them two crushed pots found in situ, were discovered in a spread of burned sand in the south-eastern corner of the house pit, and in the pit outside the house perimeter (see Fig. 4).

On the basis of these observations it can be suggested that there was a grog-tempered technological tradition within the complex of undecorated pottery, and that the date of the pottery does not seem to represent the earliest examples of this group (Ivanishcheva et al. 2016.399). However, dating of the bulk organic content (TOCC) of pottery often appears to give anomalous results (for a critical discussion of this method, see, for example, Karmanov et al. 2014; a more favourable view is proposed in Zaitseva et al. 2016).

\section{Archaeological background of Berezovaya Slobod-} ka VI

The Neolithic settlement of Berezovaya Slobodka VI is located on the a terrace approx. $8 \mathrm{~m}$ above the water level. To the north and south, it is flanked by small streams running into the river. The archaeological site covers approx. $1500 \mathrm{~m}^{2}$, of which a total of $148 \mathrm{~m}^{2}$ have been excavated. A three-chambered dwelling of $50 \mathrm{~m}^{2}$, a household area and a burial were found in the trenches (Ivanishcheva, Ivanishchev 2006.287-288). Early Neolithic pottery is represented by at least 31 vessels with pricked ornamentation.
The vessels have simple flowerpot-like shapes, with flat or flat but slightly curved bases, and rim diameters of 18 to $20 \mathrm{~cm}$. All of them have burnished surfaces (Ivanishcheva, Ivanishchev 2006.290, Fig. 3). The decoration consists of square or round pit- or dot-like impressions and are concentrated in the zone below the rim, while decoration closer to the base is rare. The clay used for these pots was tempered with grog that contains grog, and in some cases additionally with organics. Altogether, the clay fabric within this group seems rather homogenous.

\section{Dated sample and results}

One pottery fragment from this complex has been radiocarbon dated, yielding an age of $5850 \pm 90 \mathrm{BP}$ (Ki-16392) (Fig. 5; Tab. 1).

\section{Veksa 1, 3}

Archaeological background

The multi-period settlement of Veksa is a key site with regard to the cultural development of northwestern Russia. Located in the upper Sukhona basin, some $20 \mathrm{~km}$ east of the provincial capital, Vologda (Fig. 1), the site extends along the left bank of the River Vologda on both sides of a small tributary, the Veksa. The area west of the mouth of the Veksa is called Veksa 1, while the stretch to the east is named Veksa 3 (Fig. 6). Geographically, Veksa is conveniently located by an important river confluence and at the same time is not far from the Main European Watershed. Its exceptional importance is due to the clearly stratified sequence of archaeological layers up to $3 \mathrm{~m}$ thick, which encompasses all periods from the Early Neolithic via the Eneolithic, Bronze and Iron Ages through to the Medieval period (Nedomol- 


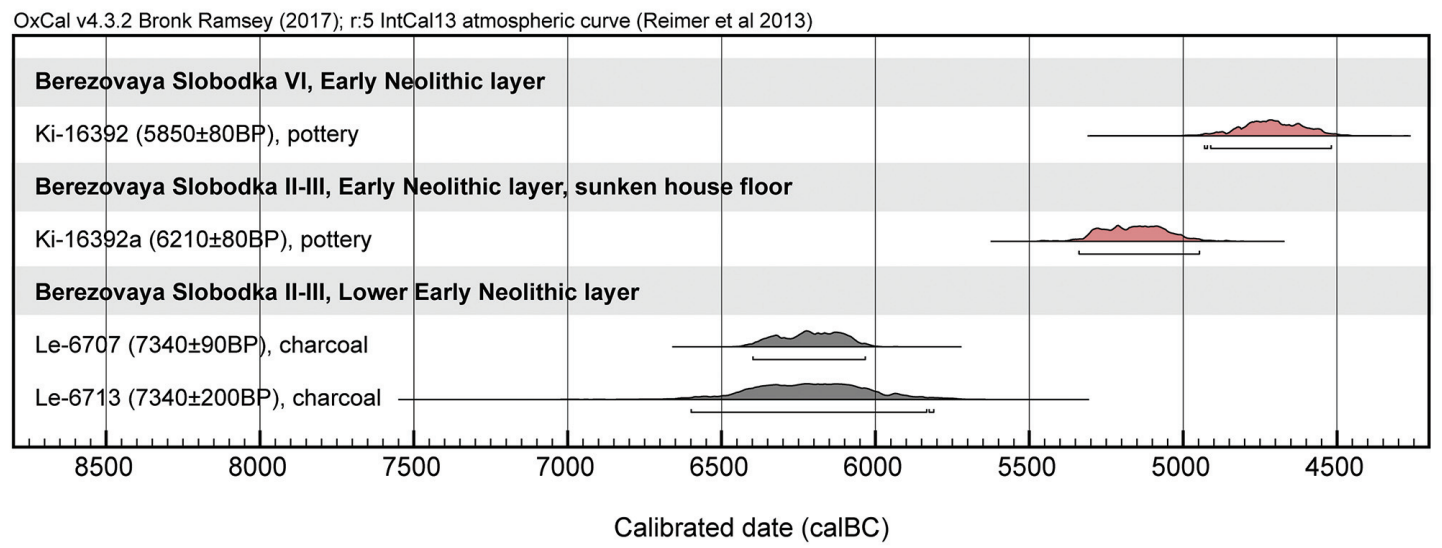

Fig. 5. Berezovaya Slobodka, Vologda province, Russia. Calibrated radiocarbon dates from Early Neolithic contexts. Dated materials: grey - charcoal; red - pottery (TOCC).

kina 2000). The Stone Age remains, which are especially well preserved due to partial water-logging, even include concentrations of wooden stakes and piles directly next to the river bank. The Veksa thus yields a rare opportunity to follow local cultural, typological and economic developments and their links to environmental history over eight millennia.

Initial archaeological work at Veksa started in 1981. Since 1993, the investigations have been directed by Nadezhda G. Nedomolkina of the Vologda State Museum-Preserve, resulting in an increased understanding of the cultural/ historical developments in the region (Nedomolkina 2000; 2004). Starting in 2007 , joint Russian-German investigations have concentrated on multi-disciplinary research at the site, including AMS radiocarbon dating, isotope and archaeochemical analyses of various materials (bone, charred pottery crusts, etc.), archaeobotany and pa- lynology, dendrochronology, geomorphology and pedology (Lorenz et al. 2012; Nedomolkina et al. 2015). This work was intensified in 2015, when a larger research project was supported by the German Research Foundation (DFG), enabling new test trenching at the site, as well as targeted research aimed at diachronic assessment of human-environment interactions and palaeolandscape reconstructions (DFG grant no. PI 1120/2-1). During two seasons of fieldwork, several test trenches were excavated, which produced dating material from various stratigraphic units, including finds from the Early Neolithic phase at Veksa 3, trench 1 (Fig. 7; Fig.8. 1, 7).

The stratigraphic sequences at Veksa 1 and Veksa 3 are distinct from each other, as not all cultural layers are present in every section of the river bank (Fig. 7). At Veksa 1, fifteen cultural layers have been distinguished, five of which date to the Neolithic peri-

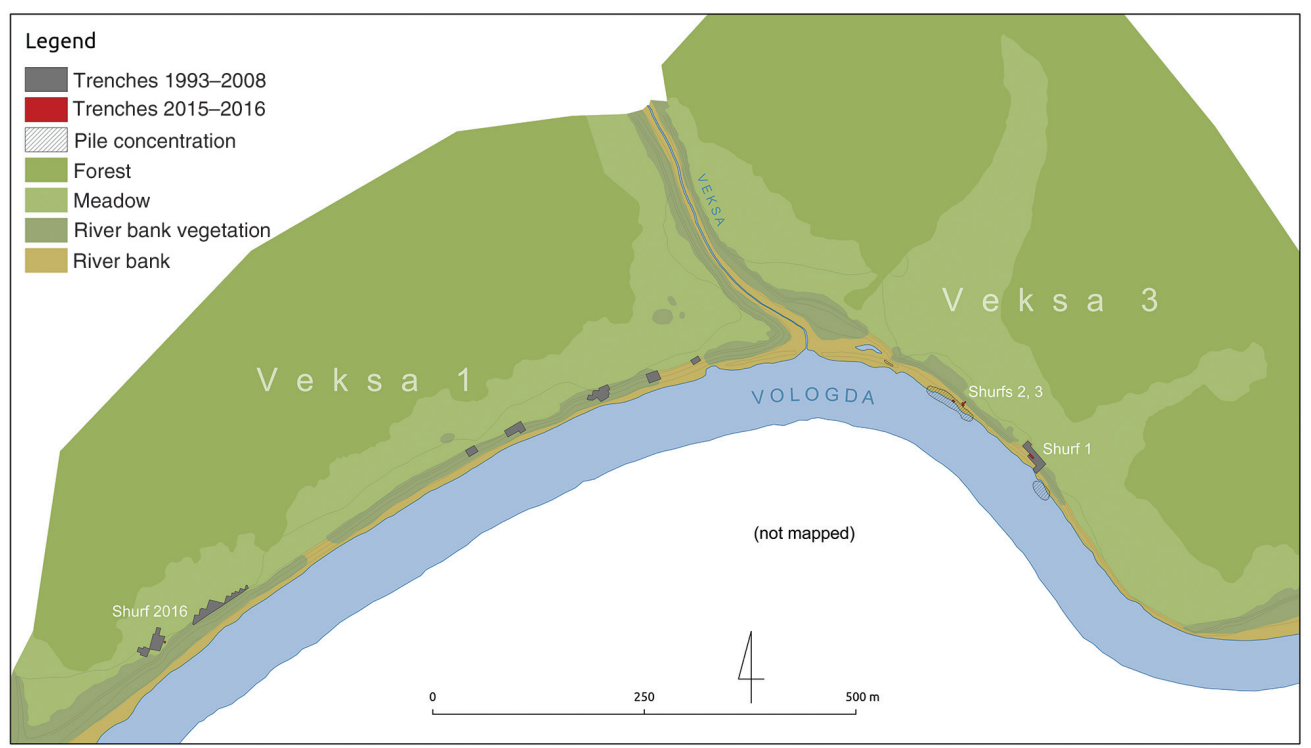

Fig. 6. Veksa 1 and 3, Vologda province, Russia. Location of old excavation trenches (grey) and new test trenches excavated in 2015 and 2016 (red) (designed by N. G. Nedomolkina and C. Engel). 
od, and at Veksa 3, nine layers were identified, with five of them stemming from the Neolithic and Eneolithic phases (Nedomolkina 2004). Geomorphological analyses have shown that all cultural layers at Veksa are embedded in floodplain sediments that developed in the Sukhona basin after a large periglacial lake dried up in the Early Holocene and a river landscape formed (Lorenz et al. 2012). The oldest archaeological complex is associated with layer

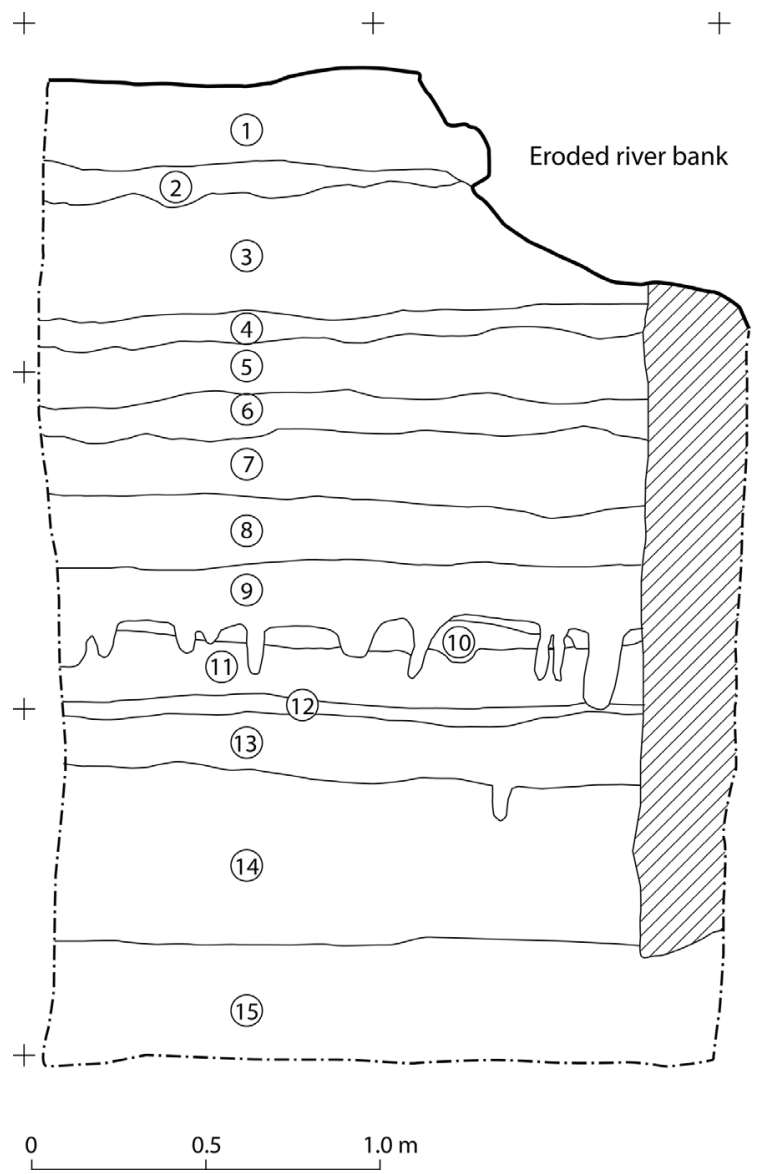

Fig. 7. Veksa 3, Vologda province, Russia. Stratigraphy at the south-eastern wall of test trench 1: 1 spoil heap of previous excavations; 2 topsoil; 3 layer 1; 4 layer 2; 5 layer 3; 6 Eneolithic cultural layer 4 with 'Porous Ware'; 7 Middle Neolithic cultural layer 5 with Pitt-Comb Ware complex; 8 layer 6; 9 Early Neolithic cultural layer 7, with pottery of the 'Northern types'; 10 Early Neolithic cultural layer 8 (upper part) with pottery of the '2nd Comb Ware complex', 11 Early Neolithic cultural layer 8 (lower part) with '2nd Comb Ware complex' and developed Upper Volga culture ware; 12 transitional zone between cultural layers 8 and 9; 13 Early Neolithic cultural layer 9, dark lens with early, sparsely decorated, and developed Upper Volga culture ware; 14 lower part of Early Neolithic cultural layer 9, sterile floodplain sediments with some anthropogenic organic lenses; 15 clayey subsoil; hatched - excavation trench 2000/2001 (designed by C. Engel).
9 at Veksa 3, located between 1.9 and $2.8 \mathrm{~m}$ below the present land surface. This layer contains several dark organic lenses at various heights, indicating successive instances of human activity on the river bank. According to the archaeological materials, these remains were connected to seasonal settlement and/or ritual activities of groups of hunter-gathererfishers who were already producing and using ceramics. The features in this horizon include rectangular post constructions with small wall trenches, repeatedly used, partly stone-lined hearths, pits, ochre, animal and fish bones in charred sediments and artefacts of various materials. The lithic finds include trapezoidal microliths; among the bone artefacts, points and fish hooks are noteworthy. Typologically, the pottery resembles the early to late phases of the Upper Volga culture, including an early complex of sparsely decorated ware, with small vessels partly with flat bases, and the typologically later so-called 'first Comb Ware complex', characterised by long vertical comb impressions and generally conical bases. This latter type is associated with the upper part of layer 9 and the lower part of layer 8 above. The '2nd Comb Ware complex' at Veksa 3, as labelled by the excavator N. Nedomolkina, is present in layer 8 between 1.8 to $1.6 \mathrm{~m}$ below the present surface. Its genesis is still not fully understood, as the complex shows typological links with the early phase of the Pechora-Dvina culture in the far northeast of Europe between the Polar Urals and the Barents Sea, and to the early Comb Ware of Tudozero 5 towards the north-west. The next layer, no. 7, at Veksa 3 contains comb-pitted ware of the so-called 'Northern types', which are also known from the upper Volga region and which have close analogies in the Säräisniemi 1 ware of northern and eastern Fennoscandia and in pit-comb ware complexes of the far northeast of Europe. Partly parallel to these 'Northern types', materials of the early phase of pit-comb ware complexes with mineral temper with affinities with the pottery of the Lyalovo and Kargopol' cultures are associated with cultural horizon $\mathrm{L}$ at Veksa 1, between 1.8 and $1.5 \mathrm{~m}$ below the present surface. In the trench excavated in 2016, this horizon related to layer 7. At Veksa 3, similar Pit-Comb Wares have been found in layer 5 , although this complex is less prominently represented here. This complex already demarcates the transition to the Middle Neolithic. At Veksa 3, the Middle Neolithic period is also represented by stray finds of organically tempered ware with rather coarse, widely spaced impressed decoration, which has its closest parallels in coeval Narva pottery of the south-eastern Baltic region (Piezonka 2008). 


\section{Dated samples and results}

A central aspect of the ongoing research at Veksa concerns the relative and absolute chronology of the anthropogenic remains, but also of their temporal interrelatedness with developments of the natural environment. A general problem for radiocarbon dating at Veksa is the poor preservation of collagen in bone from the mineral soil, making it impossible to date bone and antler artefacts from much of the stratigraphy. Previous research has resulted in a sequence of 19 radiocarbon dates (both AMS and conventional) for the Early to Middle Neolithic complexes, 18 from Veksa 3 and one from Veksa 1 (Nedomolkina, Piezonka 2016; Piezonka 2015; Piezon$k a$ et al. 2016; Timofeev et al. 2004.97) (Fig. 9; Tab. $1)$. Nine conventional radiocarbon dates were obtained on charcoal samples from layers 9, 8,6 and 5 at Veksa 3. All of them have large uncertainties, one further date with an error of \pm 700 radiocarbon years is not shown in Fig. 9 (see Tab. 1). The general stratigraphic sequence is reflected in the dates, although a more precise assessment of the absolute chronological position of the respective layers is hindered by the wide ranges of the calibrated ages. As to the onset of the archaeological sequence at Veksa 3 represented by the anthropogenic lenses in layer 9 , it most likely falls in the first half of the $6^{\text {th }}$ millennium cal BC. Henny Piezonka et al. (2016) reported AMS and EA-IRMS $\left(\% \mathrm{C}, \% \mathrm{~N}, \delta^{13} \mathrm{C}\right.$ and $\left.\delta^{15} \mathrm{~N}\right)$ results for eight food crusts on Early and Middle Neolithic pottery vessels from Veksa 3, including a second sample from a previously dated sherd and EA-IRMS results for two published AMS dates (KIA-33926; KIA-33927; KIA-33928; Piezonka 2008). Most of these sherds were from surface collections, but were sufficiently typologically diagnostic to be placed in stratigraphic sequence (Piezonka 2015.Fig. 41). EA-IRMS data were obtained for two food crusts which were too small to date (KIA-49789, KIA-49790) and three other food-crust samples (KIA-49797, KIA-49798, KIA-49799; Piezonka et al. 2016) were dated. The dated vessels encompass an early type of Comb-Pitted Ware associated with layer 9, vessels of the ' 2 nd Comb Ware complex' mainly found in layer 8 , as well as fragments of the 'Northern types', of Lyalovo pottery, and of an organically tempered ware resembling Narva culture pottery of the eastern Baltic region. Charcoal from a pit in layer 9, the lowest cultural horizon, was also dated, to provide a terminus post quem for the entire sequence (KIA-33929; Piezonka 2008). Charred crust from one Middle Neolithic vessel of Lyalovo type found as a stray find at

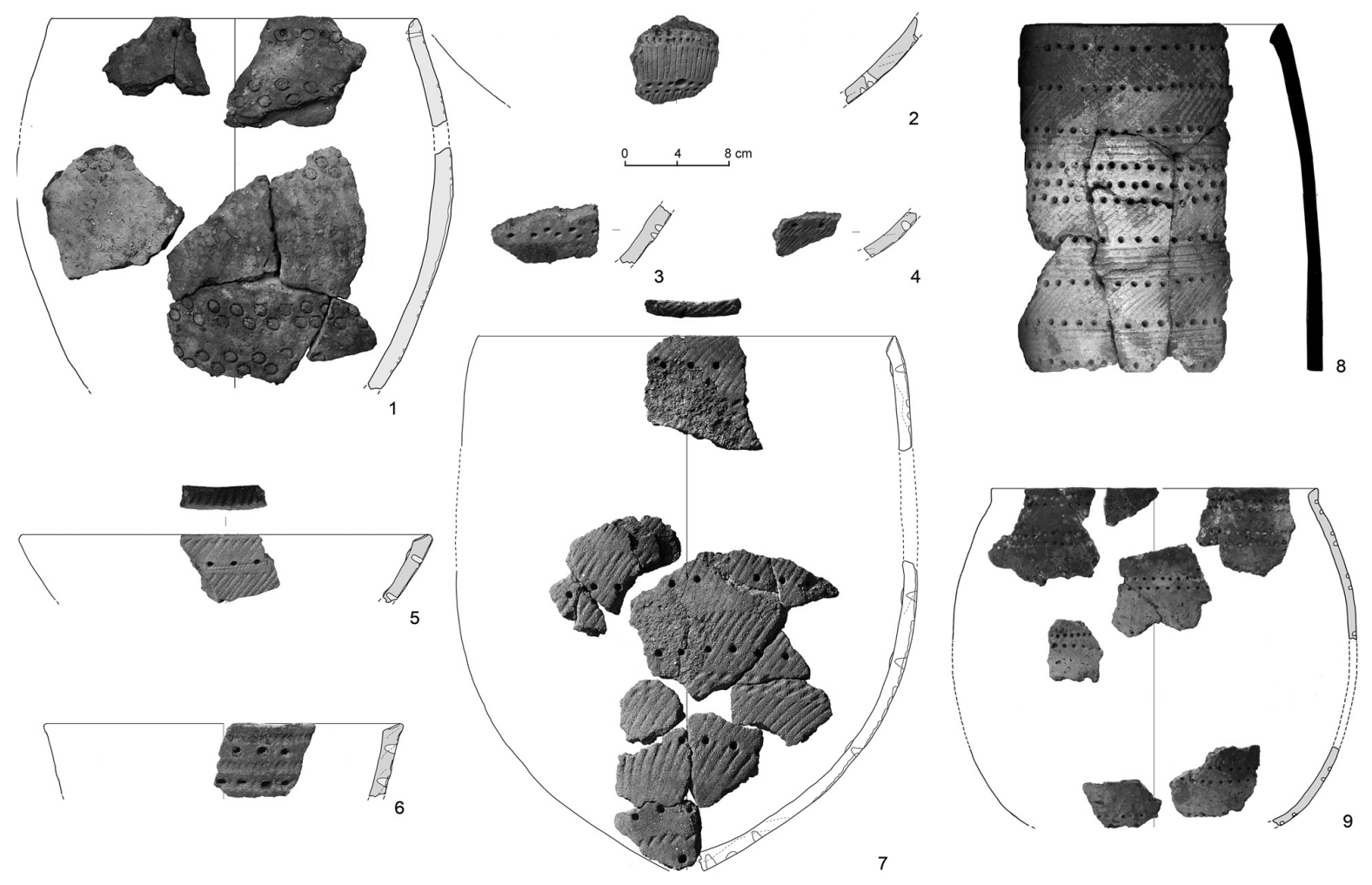

Fig. 8. Veksa 1, 3, Vologda province, Russia. Fragments of pottery from which organic residue samples were dated: 1 sample MAMS-25493; 2 sample KIA-49797; 3 sample KIA-49798; 4 sample KIA-49799; 5 sample KIA-33927; 6 sample KIA-33928; 7 samples MAMS-27311 and MAMS-27319; 8 sample SPb-1691; 9 samples KIA-33926 and KIA-49796 (designed by N. Nedomolkina and H. Piezonka). 
Veksa 1 was dated conventionally (SPb-1691; Nedomolkina, Piezonka 2016).

In the course of the new excavations in 2015 and 2016, a total of 17 AMS dates from stratified contexts at Veksa 3 and one radiocarbon date from Veksa 1 were added to this series (Nedomolkina, Piezonka 2017) (Fig. 10; Tab. 1). The stratigraphic units encompass archaeological layers, and in some cases also artificial removal horizons within the layers ('plast'), and features ('object'). The dates from stratified contexts in the test trench 1 at Veksa 3 help to test the previous chronological assumptions. The series includes ten dates on charcoal, four dates on pottery food crust, and two dates on charred seeds from edible plants (Fig. 10). One further date on charcoal (Poz-92582, 4255 \pm 35 BP, see Tab. 1) from the lowest anthropogenic context in the trench (layer 9, 'plast'
5, object 509) appears more than 2000 radiocarbon years too young for this stratigraphic unit and is not shown in Fig. 10. Since the sample provided a comparatively small amount of carbon $(0.9 \mathrm{mg}$,$) a certain$ loss of dating precision can be expected, although this does not explain the large age offset (see Tab. 1). Previous research on food-crust samples from Veksa have shown that in some cases, a substantial freshwater reservoir effect has apparently affected samples that include components of aquatic origin (Piezonka et al. 2016). Charcoal dates are not affected by freshwater reservoir effects, although here, an old wood effect might influence the reliability of the dates in comparison to the stratigraphic units. Among the potentially more reliable dates would be the results from the charred seeds of edible terrestrial plants from closed contexts, since aquatic reservoir effects as well as old wood effects can be ruled

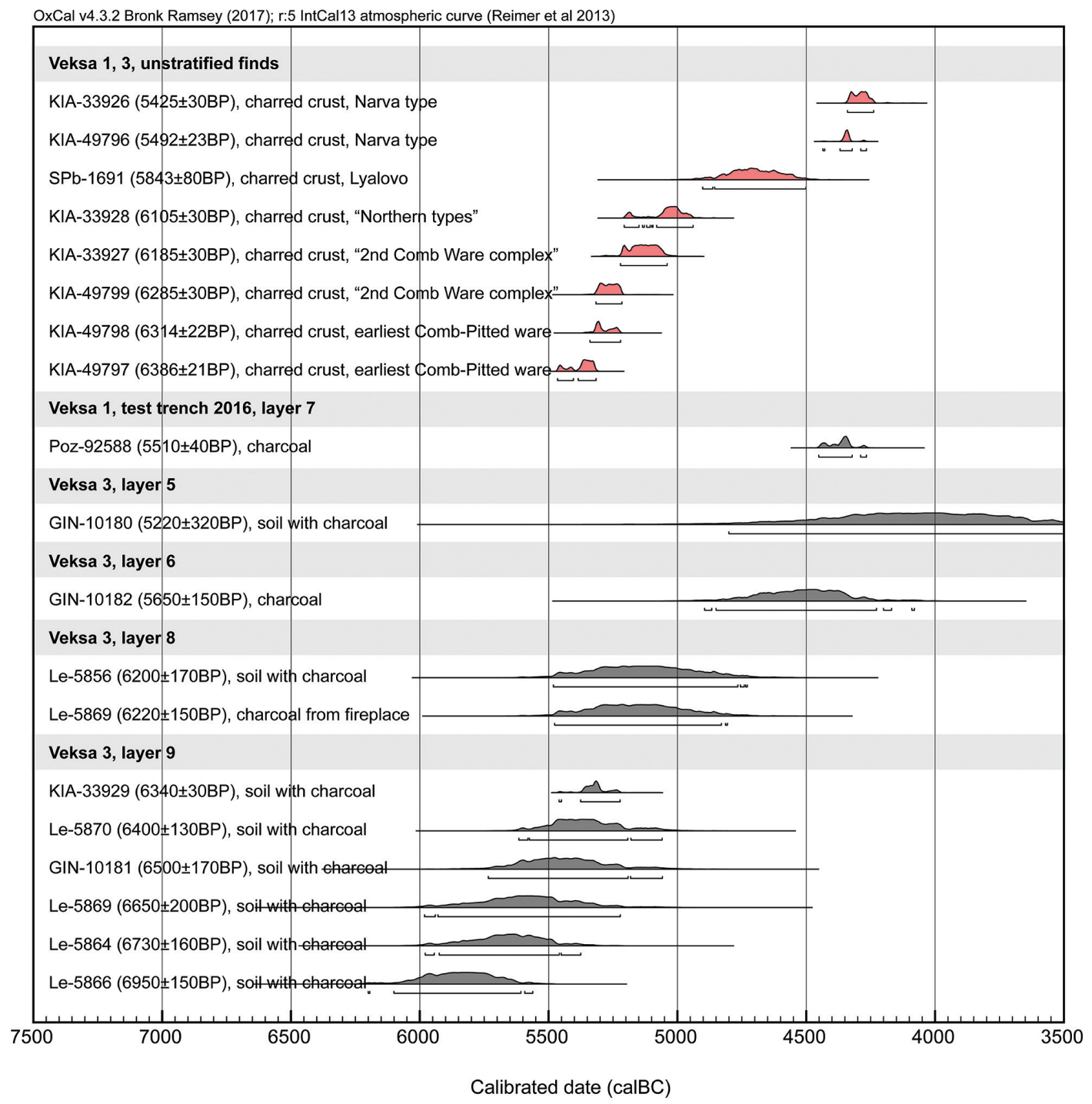

Fig. 9. Veksa 1, 3, Vologda province, Russia. Calibrated radiocarbon dates from Early and Middle Neolithic layers from old trenches and the test trench of 2016 at Veksa 1, and typologically associated material from surface collections. Dated materials: grey - charcoal; red - charred crust adhering to pottery. 


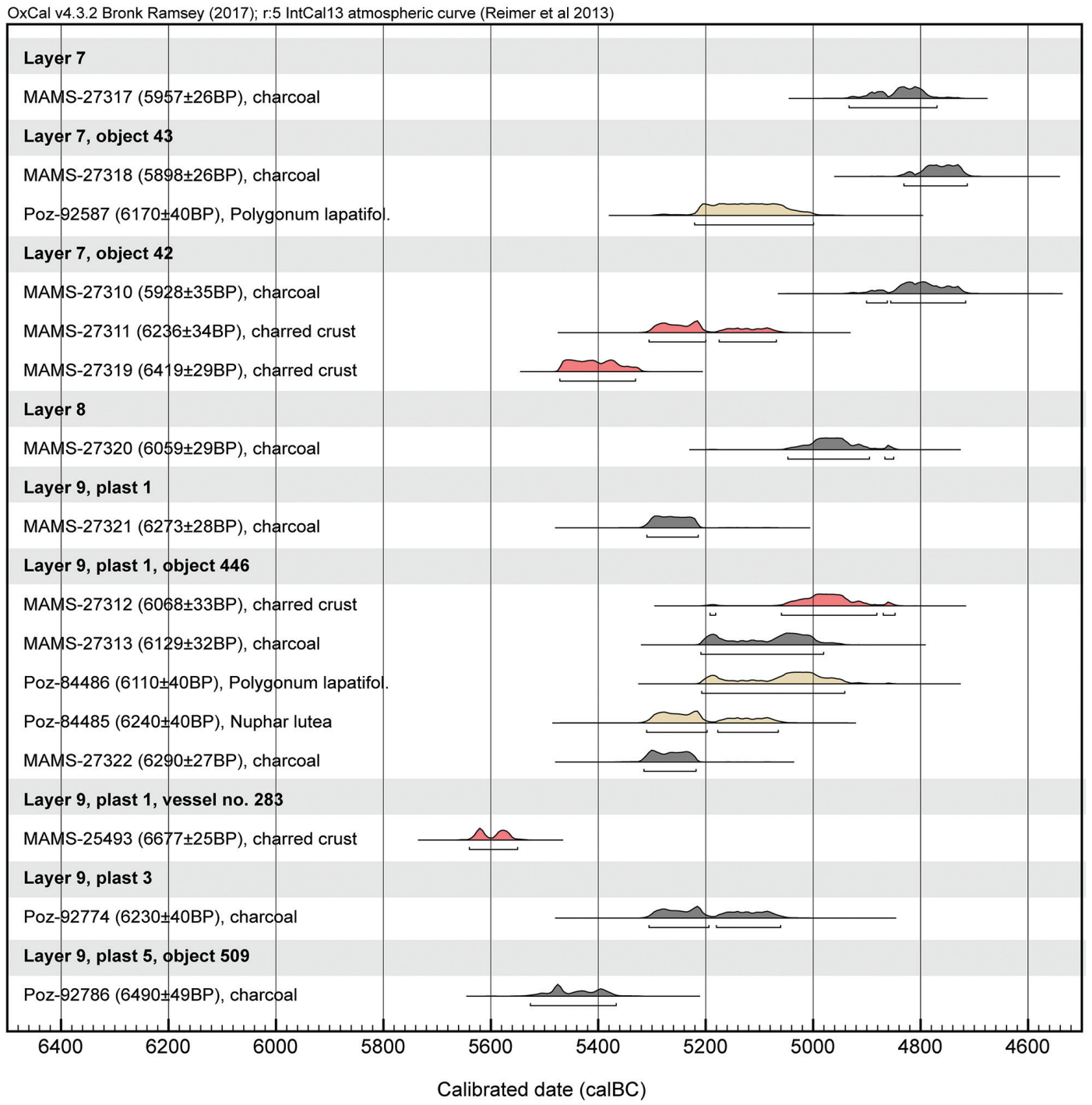

Fig. 10. Veksa 3, Vologda province, Russia. Calibrated AMS radiocarbon dates from Early Neolithic layers in test trench 1 of 2015/2016. Dated materials: grey - charcoal; red - charred crust adhering to pottery; beige - charred seeds of edible plants.

out for these. From the lowest layer, 9, eight AMS dates from various contexts and stratigraphic units exist. 'Plast' 5 of layer 9 belongs to the earliest phase of activity documented in this trench, stemming from a lens at approx. 1.95 to $2 \mathrm{~m}$ below the surface. This is reflected by the oldest AMS date on charcoal in the series, dated to the start of the second half of the

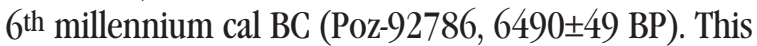
lens (object 509), which had already been partly excavated in the previous excavation trenches at Veksa 3, did not contain pottery. Thus the question arises as to whether this feature might actually represent the latest pre-pottery phase in this region. 'Plasts' 1 to 3 of layer 9 are probably associated with one and the same, somewhat later, episode of human activity on the river bank, as they encompass the dark anthropogenic horizon at the topmost part of layer 9 , between 1.6 and $1.8 \mathrm{~m}$ below the modern surface (see Fig. 7.13). Here, the charcoal and plant seed dates accord well with each other, ranging between $c .5300$ and 4950 cal BC (oldest date: MAMS-

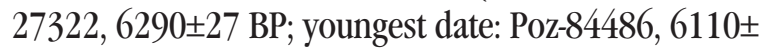
$40 \mathrm{BP})$. The two food-crust dates from pottery in the stratigraphic unit do not accord with this range, one being substantially older (MAMS-25493, 6677士 $40 \mathrm{BP}$ ), and one being statistically consistent with the latest charcoal result (MAMS-27312, 6068 $\pm 33 \mathrm{BP}$ ). The older date stems from a vessel that represents the earliest, sparsely decorated type of ceramics at Veksa (Fig. 8.1); a freshwater reservoir effect is thought to have affected the dating result. The charcoal sample from layer 8 is younger than the main reliable sequence from Layer 9, dating to the very end of the $6^{\text {th }}$ or the beginning of the $5^{\text {th }}$ millennium cal BC (MAMS-27320, 6059 \pm 29 BP). From layer 7 following above, three charcoal samples, two food- 
crust samples (the latter from one and the same vessel, Fig. 8.7) and one charred seed of Polygonum lapathifolium have been dated. The two food-crust dates from pot object 42 encompass a range between c. 5500 and $5080 \mathrm{cal} \mathrm{BC}$ and are most probably too old (MAMS-27319, 6419 \pm 29 BP; MAMS-27311, 6236 \pm $34 \mathrm{BP})$. The two dates differ from each other so substantially that they are statistically inconsistent with a single ${ }^{14} \mathrm{C}$ age. The best explanation for this would be that the results are distorted by reservoir effects, which can be different in the two samples due to heterogeneity of remains from various sources within the food crust. The three charcoal samples are in good accordance with each other in the second and third centuries of the $5^{\text {th }}$ millennium cal BC (range: MAMS-27317, $5957 \pm 26$ BP; MAMS-27318, 5898 \pm 26 $\mathrm{BP})$, including one sample stuck directly to pottery vessel object 42 , from which the two food-crust dates were obtained. They are thus between $c .300$ and 500 radiocarbon years younger than the food-crust dates. The Polygonum lapathifolium sample (Poz$92587,6170 \pm 40 \mathrm{BP}$ ) from the substantial activity zone, object 43, yielded a date almost two hundred years older than the charcoal date from this context and the other two charcoal dates from layer 7 . It rather accords with the above-mentioned date of a similar charred seed from Layer 9 (Poz-84485, 6170 $40 \mathrm{BP})$. One explanation could be that the dated seed was originally deposited in layer 9 and was subsequently dug up by later activities during the phase in which layer 7 , and with it object 43 , formed. of the documented postholes reaching down from layer 7 , however, only very few are deep enough to reach layer 9 (Fig. 7).

From the trench excavated in 2016 at Veksa 1, one charcoal sample (Poz-92588, 5510 $\pm 40 \mathrm{BP}$ ) from Middle Neolithic layer 7 , which is associated with PitComb Wares of Lyalovo type, adds to the existing three dates from Middle Neolithic finds and contexts at Veksa (Fig. 9). Dating to the third quarter of the $5^{\text {th }}$ millennium cal BC, it is more than 300 radiocarbon years younger than the food-crust date of a Lyalovo vessel found as a stray find on the river bank at Veksa 1 (Fig. 8.8) (Nedomolkina, Piezonka 2016). This difference might reflect part of the time depth of the Lyalovo phase at Veksa, which at the moment still lacks further radiocarbon evidence, but a freshwater reservoir effect in the food-crust date could also play a role here. The two food-crust dates on the Narva type vessel (Fig. 8.9), a stray find from the river bank at Veksa 3, are marginally younger than the date from layer 7 at the Veksa 1 trench of 2016. It is not clear, however, whether they could be too old due to a reservoir effect, as for this ware there is no reliable stratigraphic correlate at the moment.

\section{Lake Vozhe basin: Karavaikha 1 and 4 Archaeological background}

Lake Vozhe is situated in the north of Vologda province in Kirillov district. It is connected to the White Sea via a system of rivers and lakes. The Lake Vozhe basin can be regarded as an archaeologically well preserved landscape as recent human impact has been very slight, and it contains an astonishing wealth of preserved dryland and wetland sites. An impressive example of such good preservation sites is provided by the concentration of various sites in the locality of Karavaikha. This group of sites is located on the bank of the River Eloma, some 18km upstream from its mouth at Lake Vozhe (Fig. 1). It is situated on a slightly elevated area (approx. 1-1.5m above the mean water table) which extends approx. $100 \mathrm{~m}$ along the river bank. Aleksandr Ya. Bryusov carried out excavations in this area in the 1930s to 1950s (Bryusov 1951; 1961). He interpreted the archaeological remains as a settlement and a cemetery of the Neolithic period. Today, the site excavated by Bryusov is known as Karavaikha 1. Archaeological investigations in Lake Vozhe basin have been conducted since 2002 as a joint expedition of the State University Cherepovets and Cherepovets Museum, directed by Natalya V. Kosorukova. In the course of this work, a number of new sites were discovered in the vicinity of Karavaikha 1 (Kosorukova 2007; Kiryanova, Kosorukova 2013).

One of the most interesting of these sites is Karavaikha 4 , a wetland site which has been investigated since 2003, with excavations continuing today ( $\mathrm{Ko}$ sorukova 2008; 2014; Kosorukova, Venediktova 2014). Located approx. 150m downstream from Karavaikha 1 on the opposite, i.e. left river bank, the site occupies a low, boggy section of the bank. A total of $502 \mathrm{~m}^{2}$ were excavated between 2003 and 2015 (Fig. 11). The main cultural complex here dates to the Early Neolithic. It is located under layers of peat and gyttja at 1.2 to $1.4 \mathrm{~m}$ below the modern surface. The find horizon is associated with a thin layer of sand between the gyttja and the clayey subsoil in the riverbank area of the site, or between the gyttja and a dark brown, peaty palaeosoil farther away from the river (Figs. 12 and 13). This sandy layer is merely 1 to $2 \mathrm{~cm}$ thick in most places, occasionally reaching 3 to $5 \mathrm{~cm}$. While most of the archaeological finds are located within this layer, some have been found higher up in the lower part of the overlying gyttja. 
Two elongated narrow depressions rising up from the river have come to light in the excavated area (Figs. 11 and 12.A). Along the edges and within these depressions, several upright piles have been driven deep into the subsoil, which are the remains of wooden constructions (Figs. 11 and 12.B-C). In some cases, rows of piles apparently run across the depressions, possibly stemming from divisions or substructures of footbridges. Outside the depressions, there are some additional posts which do not display any discernible order. The depressions with the pile constructions are regarded as the remains of fishing devices placed in former inlets. This interpretation is supported by the abundance of further wooden artefacts within and around the depressions, including bark net weights and concentrations of wooden laths that could be the remains of fish fences and fish traps. Fragments of three woven fishing baskets were found lying at the base of the depressions. Archaeological finds of other materials, too, were concentrated in the depressions, most of them lying at their very bottom within a thin sandy layer and only a few in the woody layer just above it. The finds include bone and antler artefacts, flint and slate items, pottery fragments, animal and fish bones.
On the basis of the current evidence, it is assumed that the wooden piles, the finds from the woodrich layer and from the thin sandy layer below are all part of a single chronological unit, designated as the 'lower cultural layer'. It seems that this complex accumulated during the active use of this area by the ancient population that occupied the bank of the river or possibly, at that time, small lake. Human activity in later periods is attested to by sporadic finds higher up in the stratigraphy of the fill of the depressions, among them a peculiar fishing 'sledge' from the upper part of the lower fill (Kosorukova, Venediktova 2014.32-33, 38), and two wooden artefacts with carved animal heads from the middle and upper sections of the fill (Fig. 14.7-8).

\section{Dated samples and results}

Thus far, a total of 29 radiocarbon dates for Karavaikha 4 have been received, among them 26 dates from the 'lower cultural layer'. Although this lower cultural horizon is regarded on archaeological grounds as a closed context of the Early Neolithic period, the ${ }^{14} \mathrm{C}$ dates on samples attributed to this layer span a long period, from the last quarter of the $7^{\text {th }}$ millennium cal $\mathrm{BC}$ to the first third of the $5^{\text {th }}$ millennium cal BC (Tab. 1; Fig. 15). Most of these ${ }^{14} \mathrm{C}$ dates are

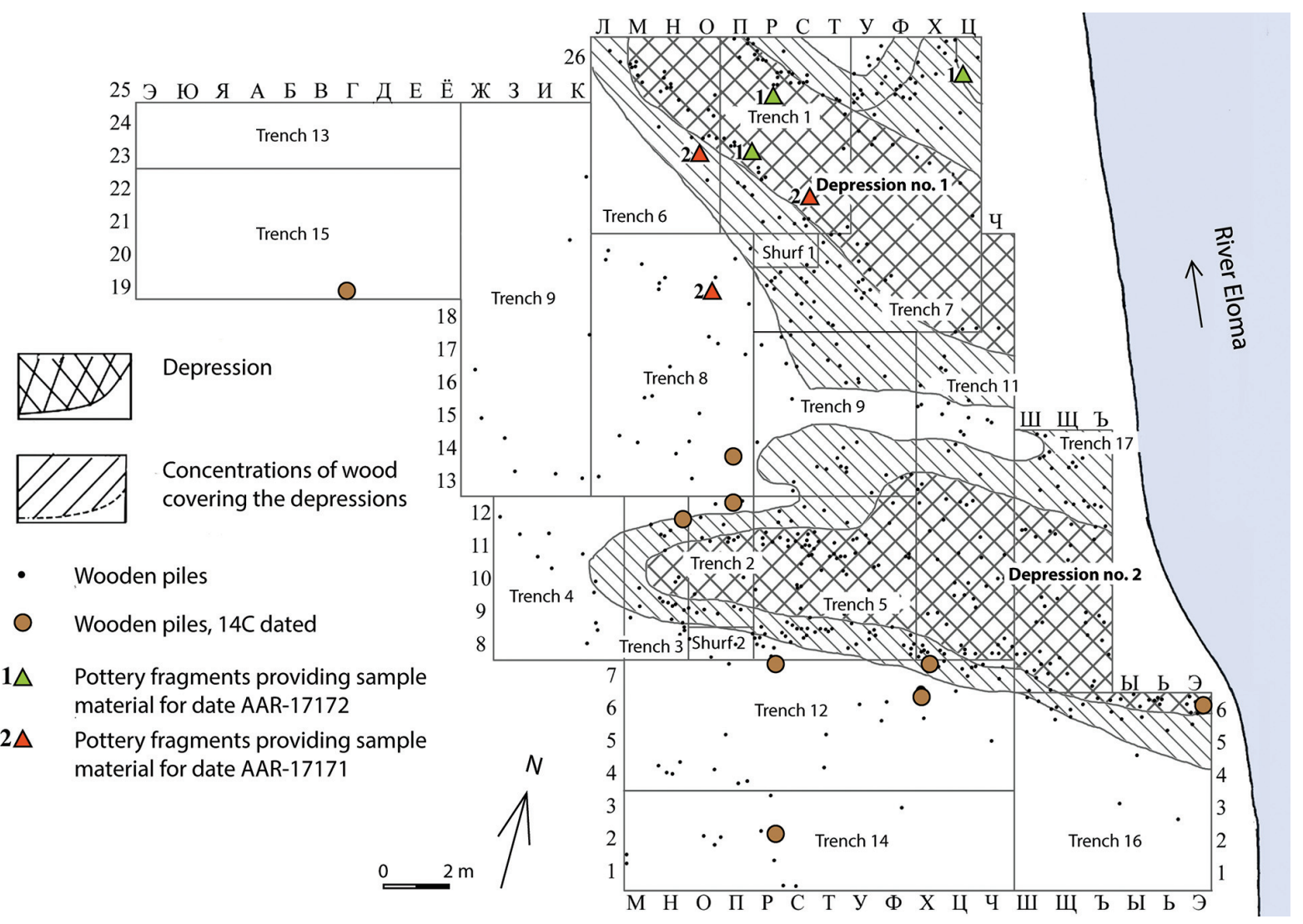

Fig. 11. Karavaikha 4, Vologda province, Russia. Excavated areas, depressions 1 and 2, upright wooden posts, and dated posts and pottery fragments on the bank of the River Eloma (designed by N. Kosorukova). 
conventional dates on wooden samples, but two AMS dates stem from charred crust on pottery fragments, and one further AMS date is from a bone artefact (Kosorukova 2007; Kiryanova, Kosorukova 2013; Kosorukova, Piezonka 2014; Kosorukova et al. 2016; Piezonka et al. 2016).

Eight dates were received for upright wooden piles driven into the subsoil. Most of the sampled piles were located along the edges of depression 2, one was situated farther away from the river, beyond the depressions (Fig. 11). The dates from the piles encompass a long period, between $7190 \pm 160 \mathrm{BP}$ (Le$10766)$ and $6310 \pm 40 \mathrm{BP}$ (Le-10771), raising the question as to whether the earliest of them might actually belong to a Late Mesolithic activity phase at this site, before the advent of pottery in the region demarcated the onset of the Neolithic. Other dated wooden samples from the lower cultural horizon in-

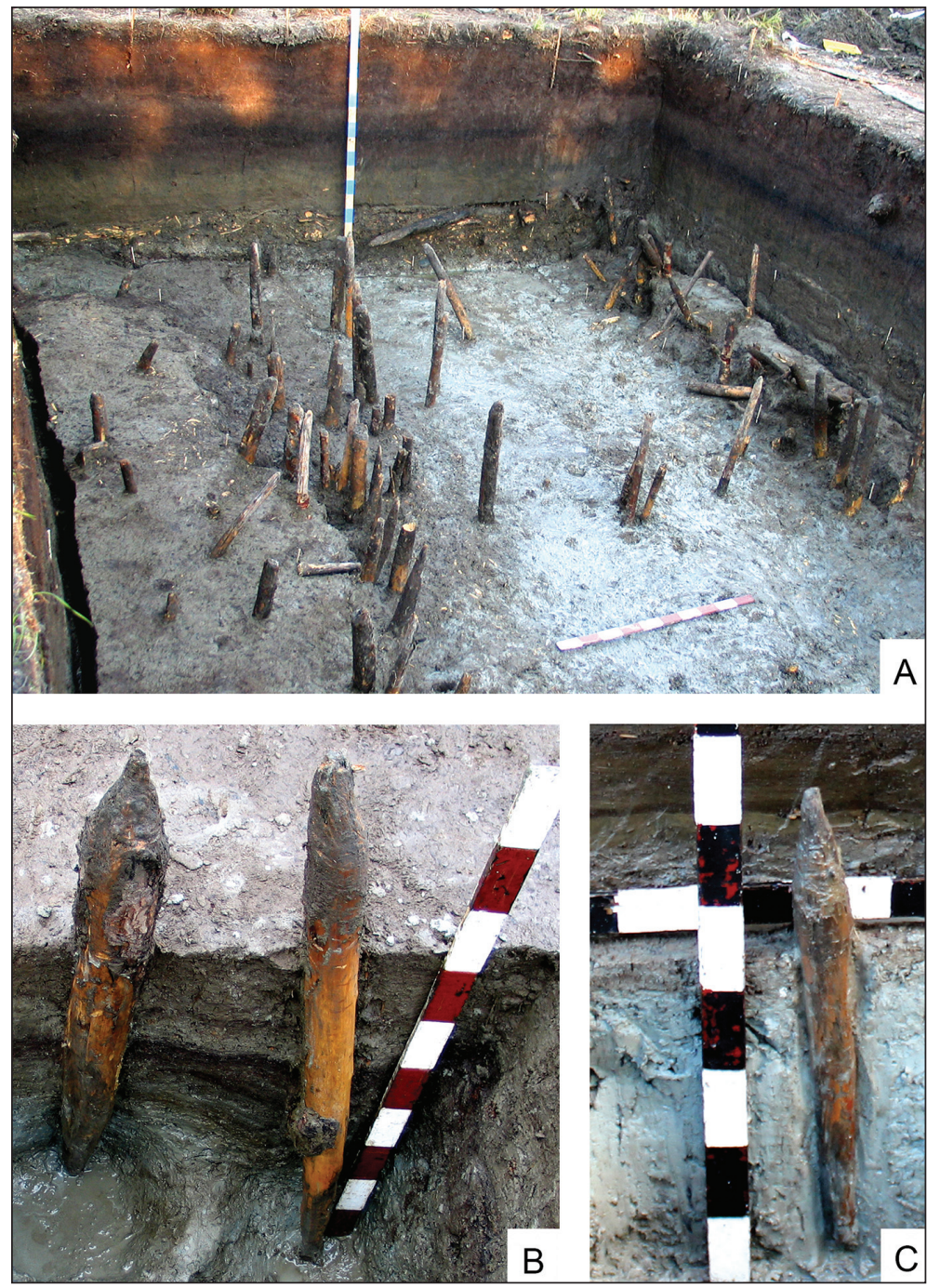

Fig. 12. Karavaikha, Vologda province, Russia. A stratigraphy and part of depression 2 in trench 5; B long posts, square M-16, trench 8; C short post, square G-19, trench 15 (photos by N. Kosorukova). clude wooden planks, rods and other worked timber from various levels below, in and above the main concentration of artefacts (see Tab. 1). While they span more or less the same time range as the wooden posts, between $7050 \pm 60 \mathrm{BP}(\mathrm{SPb}-1300)$ and $6030 \pm 130 \mathrm{BP}$ (GIN-12514), their individual dates are not necessarily in accordance with the stratigraphic sequence: While the second-oldest date of such a wooden artefact stems from a fragment found in the gyttja above the main level of artefacts (Le-7119, $7030 \pm 35 \mathrm{BP}$ ), the latest date on wood from this horizon, which is approx. 1000 years younger, is associated with a wooden batten also found in the lower part of the gyttja just above the subsoil (GIN-12514, see above) (see Tab. 1).

A bone dagger also belonging to the lower cultural complex was dated (Fig. 14.9). The dating result of $7009 \pm 40 \mathrm{BP}$ (AAR-17170) is among the oldest from this site, which is in accordance with the stratigraphical position of the artefact, at the very bottom of the archaeological sequence, at the border between the gyttja layer and the clayey subsoil below (Tab. 1). According to the stable isotope results, the sample is from a bone of a terrestrial herbivore, rendering any freshwater reservoir effect unlikely. of the two dated food-crust samples, one is from a vessel resembling comb-decorated ware of the middle phase of the Upper Volga culture (AAR-17172, 6672 \pm 31 BP; Fig. 14.1-3) and one from a typologically less specific vessel, decorated with alternating rows of various imprints of natural materials (AAR-17171, 6222 $\pm 30 \mathrm{BP}$, Fig. 14.4-6). All sampled sherds were found in or near depression 1 (Fig. 11). Most of them were found in the lower part of the gyttja that overlies the find-rich sandy layer (for more detailed information, see Tab. 1). They are thus associated with a stratum higher up the sequence than the dated bone artefact, which is reflected by their younger ages.

From the upper cultural horizon at Karavaikha 4, two conventional ${ }^{14} \mathrm{C}$ dates were obtained on the abovementioned wooden artefacts with carved animal heads (Fig. 14.7-8). 


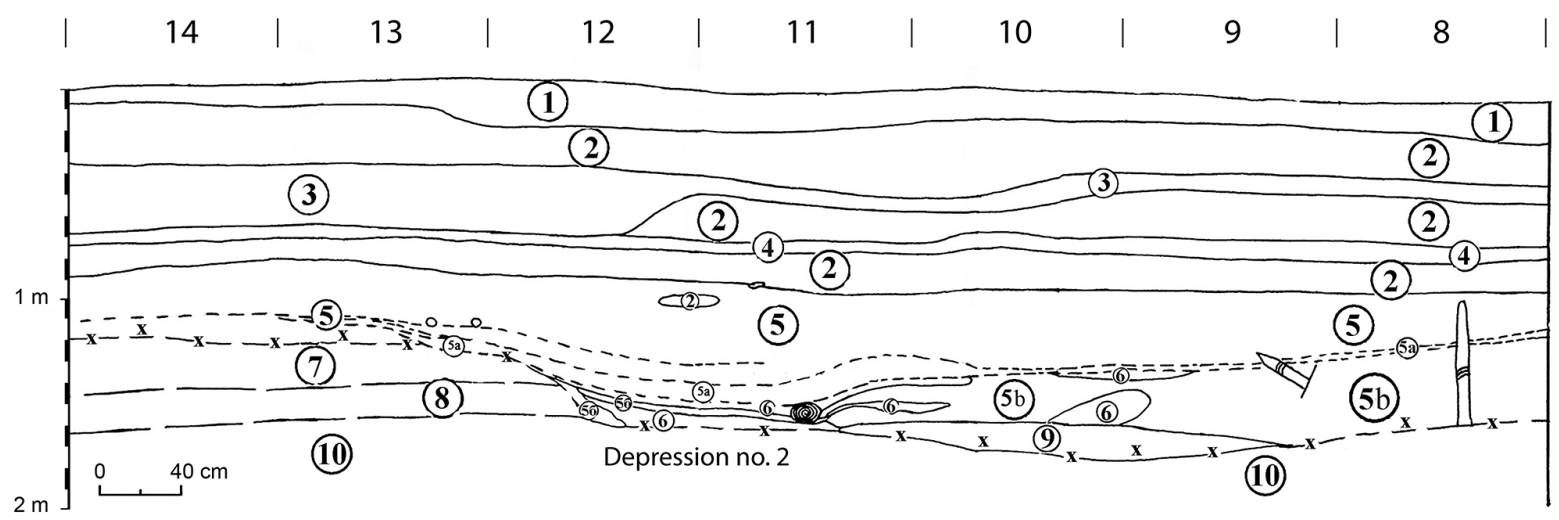

Fig. 13. Karavaikha, Vologda province, Russia. Stratigraphy at part of the eastern wall of trench 11: 1 topsoil; 2 brown peat; 3 grey brown peaty silty clay; 4 black peaty silty clay; 5 dark green peaty gyttja; 5 a dark green gyttja without peat; $5 b$ dark green peaty gyttja with wood chips; 6 light green gyttja without peat; 7 grey clay; 8 dark brown buried peat; 9 grey sand with stones; 10 light-blue clay, dashed line sand layer, $x$ - main level of finds (designed by $N$. Kosorukova).

With their ${ }^{14} \mathrm{C}$ ages of $6010 \pm 50 \mathrm{BP}$ (Le-10043) and $5990 \pm 100$ BP (Le-10044), they date to the end of the $6^{\text {th }}$ and/or the beginning of the $5^{\text {th }}$ millennium cal BC (Tab. 1).

At Karavaikha 1, situated on the opposite bank of the river, a Neolithic-Eneolithic cemetery and settlement remains from various periods have been excavated (Utkin, Kostyleva 2001). Recent test trenches at this site have yielded settlement evidence of the Middle Neolithic Kargopol culture. Charred residue from a Kargopol' potsherd was dated (AAR-17169, $5588 \pm 32$ BP; Fig. 14.10), corresponding to a date in the third quarter of the $5^{\text {th }}$ millennium cal BC.

In conclusion, it may be assumed on the basis of the dating evidence that human activity at Karavaikha 4 had already started in the Late Mesolithic in the first half of the $6^{\text {th }}$ millennium cal $\mathrm{BC}$, just before the in- troduction of ceramics. An early pottery phase is also present, and later Early Neolithic activity is attested to by the dated wooden sculptures. At Karavaikha 1, the Middle Neolithic is dated to the mid- to the later $5^{\text {th }}$ millennium cal BC.

\section{The southern part of Lake Onega basin: Tudo- zero 5}

\section{Archaeological background}

Tudozero 5 is located on the south-eastern bank of Lake Onega in the north of Vologda province in Vytegra district (Fig. 1). In Early Neolithic archaeology, it is the eponymous site for a group of sites with specific comb-decorated pottery. The stratified settlement remains are situated on a sandy spit approx. $1 \mathrm{~km}$ south of the connection between Lake Onega and Lake Tudozero. The first archaeological site was discovered on the shore of Lake Tudozero by Igor S. Polyakov during an expedition of the Imperial Rus-

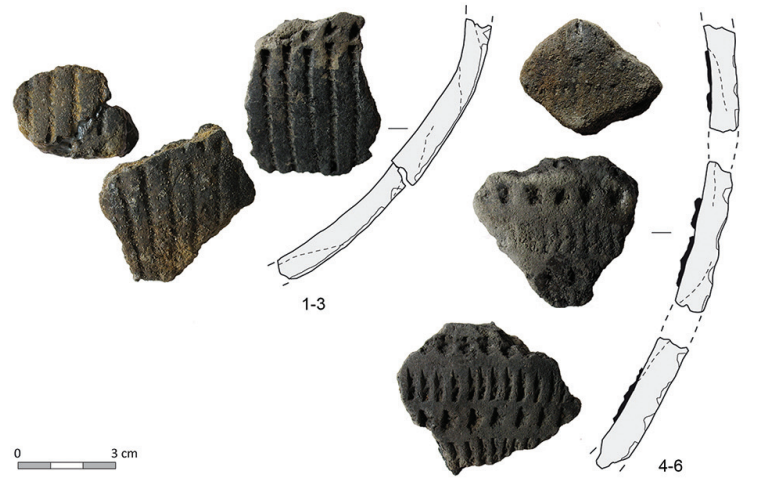

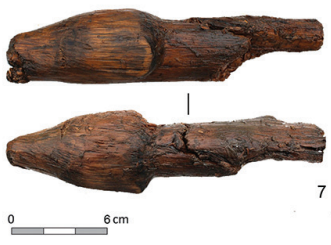
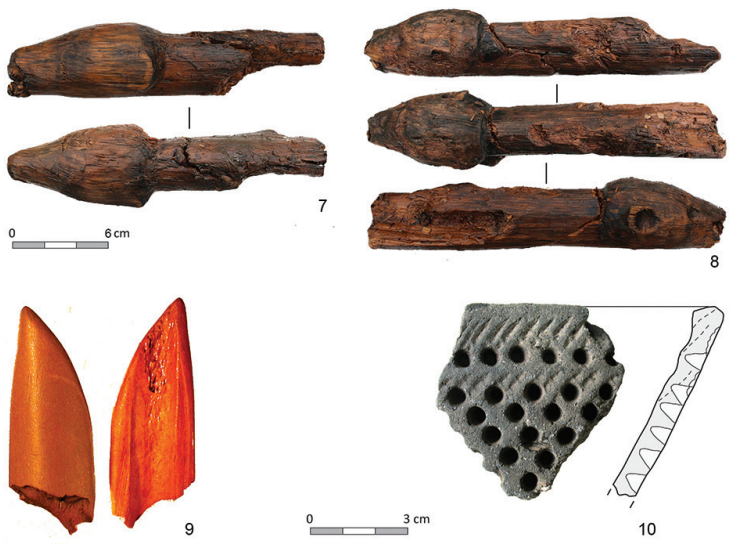

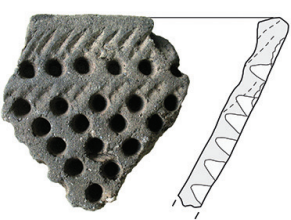

10

Fig. 14. Karavaikha, Vologda province, Russia. Dated artefacts from Karavaikha 4 (1-9) and Karavaikha 1 (10). 1-6 fragments of Early Neolithic pottery; 7-8 wooden artefacts with sculpted animal heads; 9 fragment of bone tool; 10 fragment of Middle Neolithic Pit-Comb ware. 1-3 sample AAR-17172; 4-6 sample AAR-17171; 7 sample Le-10043; 8 sample Le-10044); 9 sample AAR-17170; 10 sample AAR-17169 (designed by N. Kosorukova and H. Piezonka). 


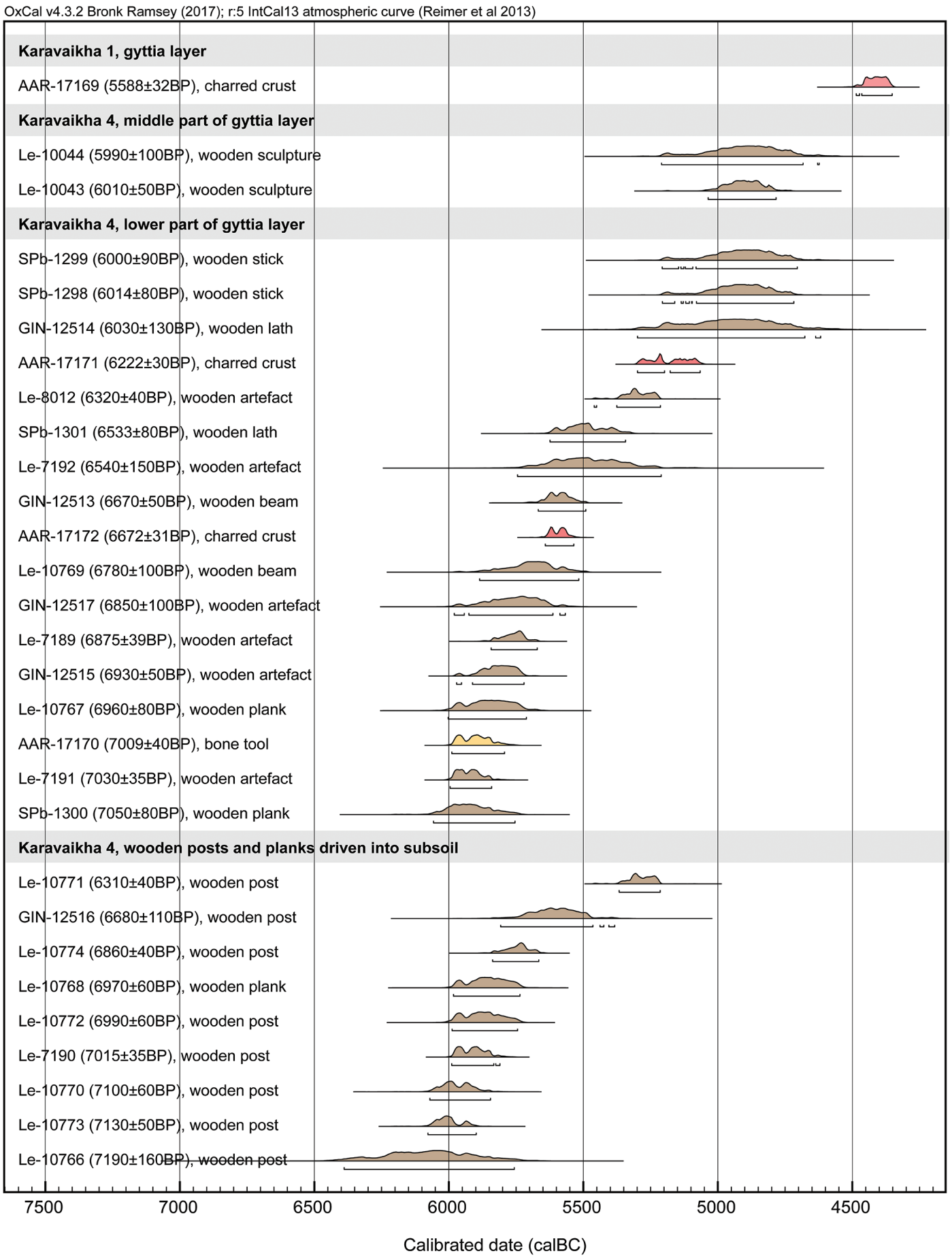

Fig. 15. Calibrated ${ }^{14}$ C dates from Karavaikha 1 and 4. Brown - wood; red - charred crust on pottery; yellow - bone.

sian Geographic Society. This site, which today is referred to as Tudozero 8, was the first known Stone Age archaeological site in the Russian north. Other sites at Tudozero were investigated by Aleksandr Ya. Bryusov in the 1940s and by Grigorii A. Pankrushev in the 1970s. The work of the Northern Archaeological Expedition of the Institute of Archaeology of the Academy of Sciences of the USSR, which was directed by Svetlana V. Oshibkina, included investiga- tions of a medieval settlement led by Nikolai A. Makarov. Since 1986, the investigations of archaeological remains at Tudozero have been carried out by the Vytegra team of the Northern Archaeological Expedition, directed by Aleksander M. Ivanishchev. In the course of these works, a large area has been excavated at the multi-period stratified site of Tudozero V. Recently, geochemical and palynological studies have been conducted at Tudozero in order to 
reconstruct the changing environmental conditions and to better understand human-environment interactions in the southern Onega region (Ivanishcheva et al. 2015).

The archaeological site is partly located in a natural depression on the spit which opens up to Lake Onega. The site encompasses an area of approx. $2800 \mathrm{~m}^{2}$, $1276 \mathrm{~m}^{2}$ of which have been excavated (Fig. 16). To the north of the depression on higher ground, a Stone Age cemetery spanning the Mesolithic and Early Neolithic periods has been investigated (Ivanishchev, Ivanishcheva 2006). The archaeological sequence of the settlement site comprises evidence from the Mesolithic through to Medieval times; it reaches up to $2.9 \mathrm{~m}$ below the modern land surface (Ivanishcheva et al. 2015) (Fig. 17). The so-called 'lower cultural horizon' on top of the sandy subsoil includes Mesolithic and Early Neolithic cultural layers. The cultural horizon of the Early Neolithic period, which is especially well represented in the lower-lying part of the ancient depression, lies above the Mesolithic layer, separated from it by a sterile layer of dark yellow sand. It is overlain by a substantial sterile layer of yellow sand up to $1.5 \mathrm{~m}$ thick. In the upper part of the stratigraphy, cultural remains from the Middle Neolithic, characterised by Pit-Comb Ware, through to the Middle Ages are intermixed.

In the Early Neolithic horizon, which is of interest here, two cultural layers can be distinguished in parts of the site. They are separated from each other by a band of sterile sand between 0.25 and $0.4 \mathrm{~m}$ thick, and differ both in artefact density and the archaeological objects contained in them (Ivanishcheva 2014.256; Ivanishcheva et al. 2015) (Fig. 17.strata 10 and 8). Altogether, no fewer than 290 pottery vessels are represented in the ceramic material from this horizon. Of the 161 pottery vessels found in the lower Early Neolithic layer (stratum 10 in Fig. 17), 101 belong to a pre-Sperrings type of early Comb Ware characterised by comparatively small vessel sizes with conical bases, relatively thin walls and straight rims. The decoration covers the entire surface, and consists mainly of horizontal or oblique bands of short comb stamp impressions set closely together (see Fig. 18.1). The tempering material includes mineral and organic components and, to a lesser extent, grog. The archaeological features documented in this layer include numerous hearths, ash concentrations, and domestic and ritual pits, as well as steps leading into the natural depression, which were repeatedly strengthened by wooden constructions. The excavators interpret the evidence from this layer either as the remains of long-term, possibly year-round habitation, or of repeated visits over a long period (Ivanishcheva et al. 2016). According to the geochemical and palynological results, the period in which this layer formed is connected to the onset of warmer and more humid climatic conditions in the Atlantic period (Ivanishcheva et al. 2015. 287-288). The upper Early Neolithic layer (stratum 8 in Fig. 17) is less rich in finds. The artefacts were concentrated mainly in amorphous hearth-like features, with dark fills that contained ochre, burnt sand and charred organic materials, and in kitchen debris around these hearths. This layer is thought to have originated from short-term stop-overs by fishers at the lake shore (Ivanishcheva 2015; Ivanishcheva et al. 2016). The pottery in this layer includes vessels with impressions of fish vertebrae that are typical of the early phase of the Sperrings culture of Karelia and southern Fennoscandia (Nordqvist, Mökkönen 2016; Piezonka 2015) (see Fig. 18.2). Here, the decoration consists of horizontal rows of impressions that cover most of the vessel surface, but with a blank strip below the rim. Secondary motifs such as single rows of pit-like impressions sometimes overprint the main ornamentation, a feature highly typical feature of Sperrings ware. According to the geochemical results, the formation of this cultural layer coincided with a drier and cooler climatic episode (Ivanishcheva et al. 2015.288).

\section{Dated samples and results}

A total of eight radiocarbon dates have been received for materials from the two Early Neolithic cultural layers at Tudozero 5, including two AMS dates on charred food crusts on pottery and six conventional dates on charcoal from hearths and other features (Ivanishcheva et al. 2016; Piezonka et al. 2016) (Fig. 19; Tab. 1). The two pottery vessels sampled for AMS dating represent the two chronotypological groups in question, the pre-Sperrings Early Comb Ware from the lower layer (Fig. 18.1, AAR-17174, $6660 \pm 32 \mathrm{BP}$ ), and a typical Sperrings vessel from the upper Early Neolithic horizon (Fig. 18.2, AAR$17173,6241 \pm 30 \mathrm{BP})$. Both the charred crust and the charcoal dates are in accordance with the stratigraphical observation in parts of the site that two Early Neolithic phases occur at Tudozero 5 (Fig. 19). Altogether, most of the dates suggest that the chronological position of the lower Early Neolithic layer with the Early Comb Ware complex lies in the second quarter of the $6^{\text {th }}$ millennium cal BC (AAR-17174, $6660 \pm 32 \mathrm{BP}$ and Le- $6700,6600 \pm 25 \mathrm{BP}$ ), and a time bracket for the upper Early Neolithic layer with the Sperrings complex falls in the last quarter of the $6^{\text {th }}$ 
and the beginning of the $5^{\text {th }}$ millennium cal $\mathrm{BC}$ (GIN-8050, 6250 \pm 50 BP to Le-6699, 6075 $\pm 20 \mathrm{BP}$ ). However, one conventional date that also stems from the lower Early Neolithic horizon appears unexpectedly old (TA-2354, 7240 $\pm 60 \mathrm{BP}, 6226-6022$ cal BC). The dated material is charcoal from a wooden plank that lay at the base of the lower Early Neolithic layer (Ivanishcheva et al. 2016.408); an oldwood effect or a re-location from the Mesolithic complex at this site could be responsible for the age offset. For the Mesolithic layer below, a conventional radiocarbon date on charcoal produced an age of $8280 \pm 35$ BP (Le-6701, 7459-7186 cal BC) (Ivanishcheva et al. 2015.287). The age difference of around one thousand years between the two latter dates is

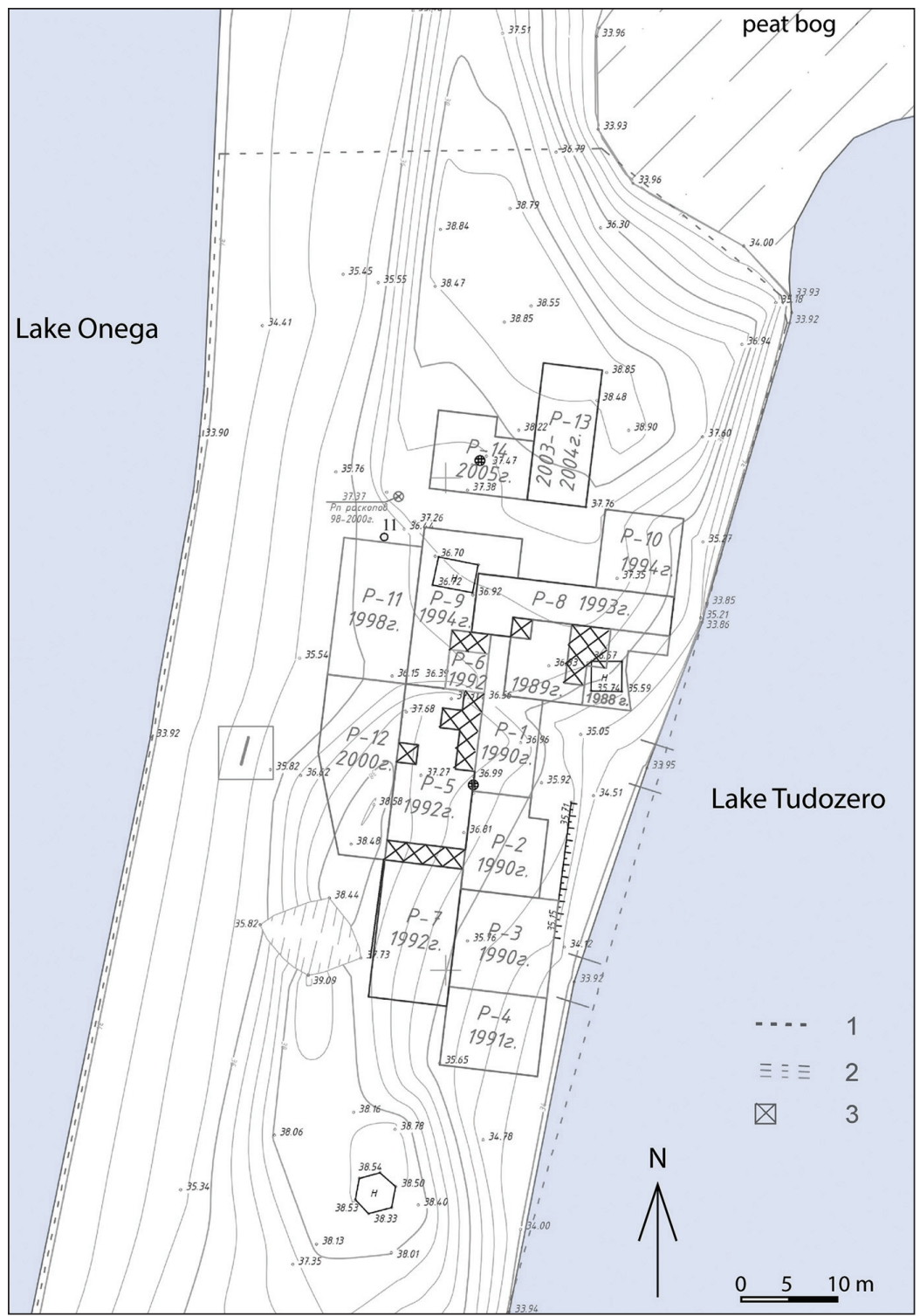

Fig. 16. Tudozero 5, Vologda province, Russia. Excavated area on the sandy spit between Tudozero and Onega lakes: 1 limit of settlement site; 2 borders and numbers of excavation squares; 3 squares not excavated (designed by A. Ivanishchev, M. Ivanishcheva). in general accordance with the stratigraphic sequence. Geochemical analyses point to human activities at the site also during the period when the sterile layer between the Mesolithic and the Early Neolithic cultural horizons were formed (Kulkova et al. 2014.197). Thus the date in question might also be connected to these intermediate activities, for which further archaeological evidence is not yet available.

\section{Discussion}

\section{Early Neolithic}

The radiocarbon dating evidence for the Early Neolithic between the Sukhona and southern Onega regions of northern Russia has been expanded in recent years by a number of AMS dates, and today, more than 70 dates exist for the most important archaeological sites. While many of these dating results are consistent with the stratigraphy and the expected typological sequences, two dates at Berezovaya Slobodka by the River Sukhona and one date at Tudozero at the southern end of Lake Onega, as well as several dates from $\mathrm{Ka}$ ravaikha 4 that are thought to be stratigraphically associated with the Early Neolithic phase appear to predate the end of the $7^{\text {th }}$ millennium cal BC. None of these early dates is unquestionably associated with pottery at the sites. Direct dates on pottery start only in the second quarter of the $6^{\text {th }}$ millennium cal $\mathrm{BC}$, and even these are in some cases suspected to be too old due to reservoir effects. Compared to the evidence from surrounding regions, an onset of pottery use, and with it of the Neolithic period, as early as $c .6000 \mathrm{cal} \mathrm{BC}$ in these northern areas would appear surprisingly early. In the Upper Volga region, recent dating programmes on the site of Zamost'e indicate an initial appearance of ceramics around $5700 \mathrm{cal} \mathrm{BC}$ (Meadows et al. 2015), and at Sakhtysh 2a and Ozerki 5, dates that predate 5800 cal $\mathrm{BC}$ are thought to be possibly affected 


\section{$0 \quad 10 \quad 30$}

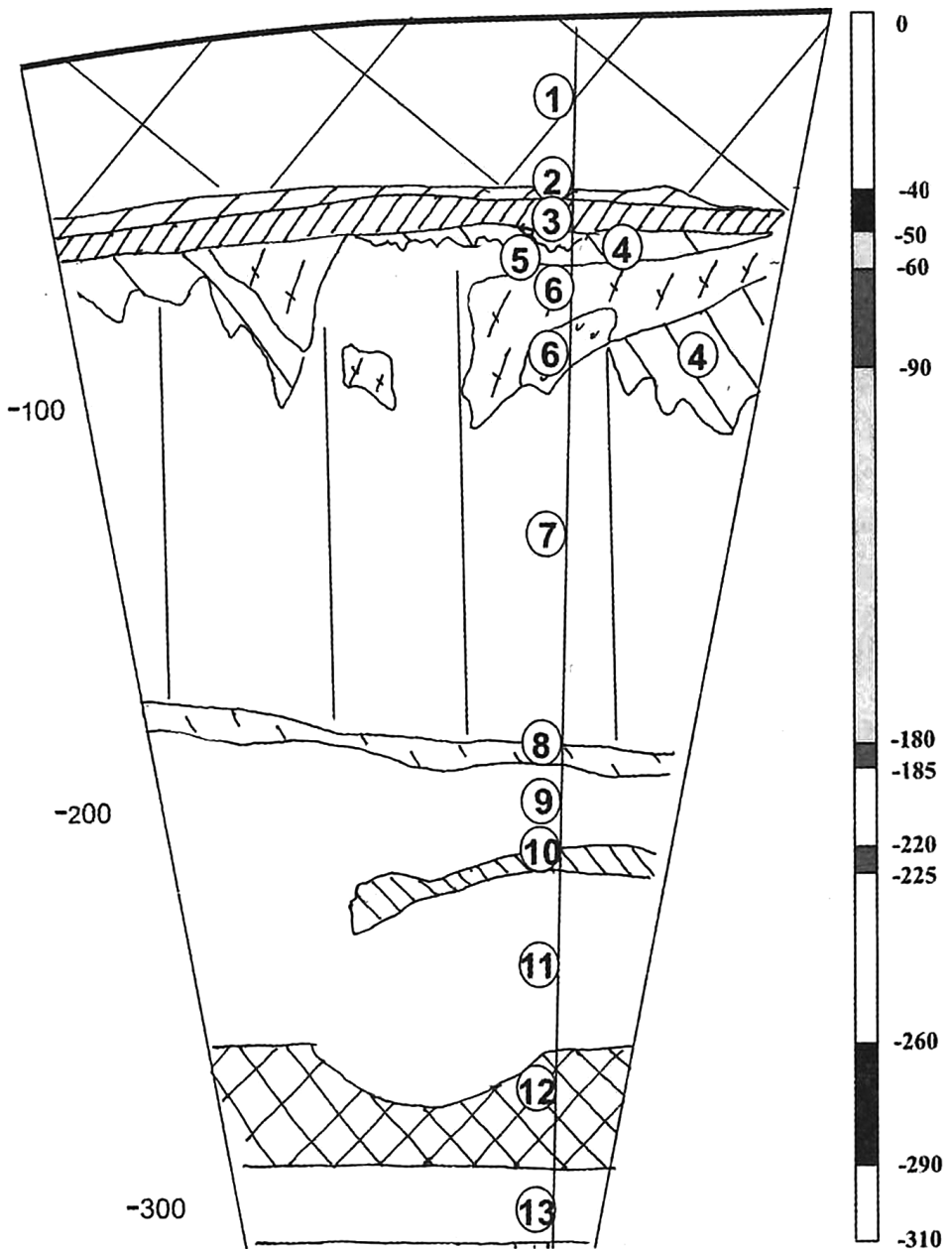

Fig. 17. Tudozero 5, Vologda province, Russia. Stratigraphy: 1 topsoil (dune sand); 2 Late Medieval cultural layer; 3 cultural layer of developed Medieval period; 4 pinkish sand, without finds; 5 dark yellow sand, without finds; 6 Early Iron Age cultural layer; 7 dark yellow sand, without finds; 8 Early Neolithic cultural layer 1, with Comb Ware and Sperrings pottery; 9 dark yellow sand, without finds; 10 Early Neolithic cultural layer 2, with Comb Ware; 11 dark yellow sand, without finds; 12 Mesolithic cultural layer; 13 light yellow sand, subsoil (designed by M. Ivanishcheva).

by reservoir effects (see Hartz et al. 2012). Farther east, west and north, the earliest pottery appears only from the middle of the $6^{\text {th }}$ millennium cal BC onwards (Karmanov et al. 2014; Zajtseva et al. 2016; see also Piezonka 2015).

The food-crust dates appear to have been distorted by freshwater reservoir effects in some cases, but it is difficult to assess the scale of this problem without more precise chronologies, particularly for shorter phases of occupation. In long occupational sequences, without tight stratigraphic control over all dated materials, it is difficult to detect radiocarbon age offsets of a few hundred years. Assuming that food- crust stable isotopes and elemental abundances reflect those in the original ingredients, the dated food crusts from Veksa appear to show an increasing use of fish over time, with more terrestrial values from the earliest samples (Piezonka et al. 2016). We have no direct evidence yet that there was a significant FRE at Veksa in the Neolithic. However, two recent fish from the Vologda River, collected in September 2015, were dated by AMS; both have apparent ${ }^{14} \mathrm{C}$ ages of $c .1100$ years (Tab. 2). If mid-Holocene fish were similarly depleted in ${ }^{14} \mathrm{C}$, the ages of food crusts from this region where fish was a major dietary component would appear to be centuries older than contemporaneous terrestrial plants and animals as sources of carbon. At nearby Minino, the large dietary reservoir effects in prehistoric human remains (Wood et al. 2013) imply that early-mid Holocene fish had very high FREs. In the case of Veksa, however, we can rely on the stratigraphic sequence of ${ }^{14} \mathrm{C}$ dates from wood and charcoal samples to provide a realistic chronology for the Neolithic pottery types.

At Karavaikha 4, fourteen ${ }^{14} \mathrm{C}$ dates from the lower cultural horizon, most of them on wooden artefacts, span a very long period from $7050 \pm 80 \mathrm{BP}$ (SPb-1300) to $6030 \pm 130$ BP (GIN12514), contradicting the assumption that this horizon represents a confined Early Neolithic episode of human activity (Fig. 15). The date of the bone dagger (AAR-17170, 7009 \pm 40 BP) is among the oldest (Tab. 1), indicating a human presence at the site in the first third of the $6^{\text {th }}$ millennium cal $\mathrm{BC}$, a period associated with the aceramic Late Mesolithic in these parts of Northern Russia (Filatova 2006). The earliest date directly associated with pottery at Karavaikha 4 stems from the food crust from vessel 5 (AAR-17172, 6672 $\pm 31 \mathrm{BP}$ ), which is typologically similar to pottery of the second phase of the Upper Volga culture. This date forms a group with four broadly contemporary conventional dates from wood samples. Compared to dates for the developed phase of Upper Volga pottery elsewhere, however, the date from Karavaikha 4 seems too early. Food-crust dates for typologically connected 


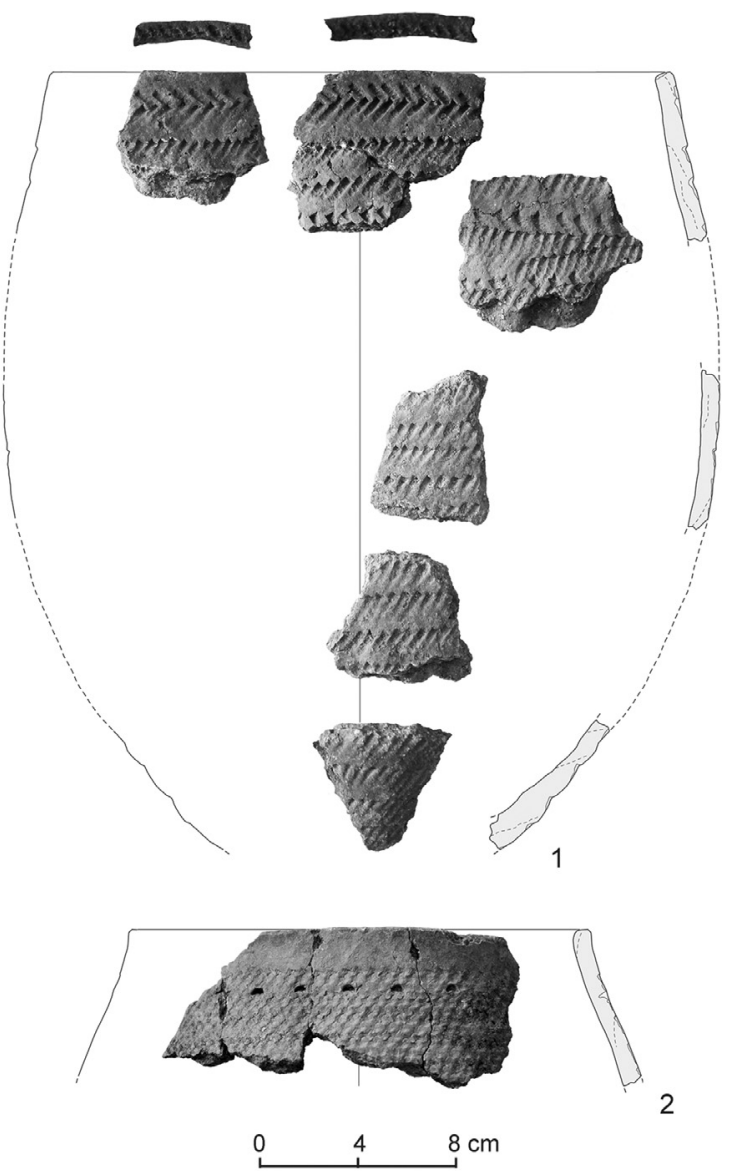

Fig. 18. Tudozero 5, Vologda province, Russia. Fragments of pottery from which organic residue samples were taken: 1 sample AAR-17174; 2 sample AAR-17173 (designed by H. Piezonka).

wares and their contexts from Veksa 3, Sakhtysh 2a and Ozerki 17 (Hartz et al. 2012) are approx. 400 ${ }^{14} \mathrm{C}$ years younger. Therefore, a significant FRE could have affected AAR-17172. The second food-crust date from Karavaikha 4 (AAR-17171, 6222 \pm 30 BP) is the second-youngest date associated with the lower cultural horizon. Its typological attribution is not as straightforward as with other vessel unit. While the composition of the decoration stylistically resembles the 'Northern Types', the use of irregular stamps instead of large, deep pits, is an atypical feature. The dating result appears marginally older than that for 'Northern Type' pottery from Veksa (KIA33928). There are no other dates for contexts with this type of pottery at Veksa or in the Upper Volga region. Altogether, the chronology of the lower cultural horizon at Karavaikha 4 is not fully understood, and it seems possible that several phases of activity during the Late Mesolithic and Early Neolithic are represented. To understand the chronological setting of the pottery associated with it and to judge the possible presence of FREs in its food crusts, dating of securely associated terrestrial material will be necessary.

The two food-crust dates from Tudozero 5 fit both the stratigraphic sequence and existing conventional ${ }^{14} \mathrm{C}$ dates from the respective layers (Fig. 19). They thus appear to confirm the assumption that the local early Comb Ware is associated with an Early Neolithic horizon dating to the second quarter of the $6^{\text {th }}$ millennium cal $\mathrm{BC}$, while Sperrings pottery dates to a later phase of the Early Neolithic in the last third of the $6^{\text {th }}$ millennium cal BC. Altogether, the stratigraphic and typological evidence and associated ${ }^{14} \mathrm{C}$ dates suggest that no substantial FRE has affected the food-crust dates from Tudozero 5 . At the same time, the EA-IRMS results and especially the high $\delta 15 \mathrm{~N}$ values suggest a significant aquatic component. Here, too, comparative dating of terrestrial and aquatic materials from closed contests would help to better understand these questions, and radiocarbon dating of modern fish would also provide a general impression whether or not FREs have to be taken into account for aquatic materials from the local water systems.

\section{Middle Neolithic}

In the present study, five radiocarbon dates from Middle Neolithic contexts or finds are discussed. The dating of food-crust from a typical Lyalovo culture vessel that was found as a surface find at Veksa 1 resulted in an age in the second quarter of the $5^{\text {th }}$ millennium cal BC, which is within the chronological range of the early phase of the Lyalovo culture.

\begin{tabular}{|c|c|c|c|c|}
\hline Laboratory code & Sample & AMS $\delta^{13} \mathrm{C}(\% \circ)$ & Conventional ${ }^{14} \mathrm{C}$ Age & Apparent ${ }^{14} \mathrm{C}$ Age \\
\hline KIA-51318 & Vologda fish \#41 (small white fish) & $-30.44 \pm 0.13$ & $912 \pm 23$ & $1065 \pm 23$ \\
\hline KIA-51319 & Vologda fish \#42 (perch) & $-34.41 \pm 0.11$ & $932 \pm 31$ & $1085 \pm 31$ \\
\hline \multicolumn{5}{|c|}{$\begin{array}{l}\text { Apparent }{ }^{14} \mathrm{C} \text { age calculation based on atmospheric }{ }^{14} \mathrm{C} \text { activity of } 1.0193 \pm 0.0004 \mathrm{~F}^{14} \mathrm{C} \text {, average of May-August atmos- } \\
\text { pheric data for } 2015 \text { (Hammer, Samuel, and Ingeborg Levin. } 2017 \text {. Monthly mean atmospheric } \Delta^{14} \mathrm{CO}_{2} \text { at Jungfraujoch } \\
\text { and Schauinsland from } 1986 \text { to } 2016 \text {. heiDATA Dataverse) }\end{array}$} \\
\hline
\end{tabular}

Tab. 2. AMS results from samples of dry fish flesh. Both fish were caught in September 2015 in the Vologda River, Vologda City, Russia. The samples were freeze-dried and combusted for dating without further pretreatment. 


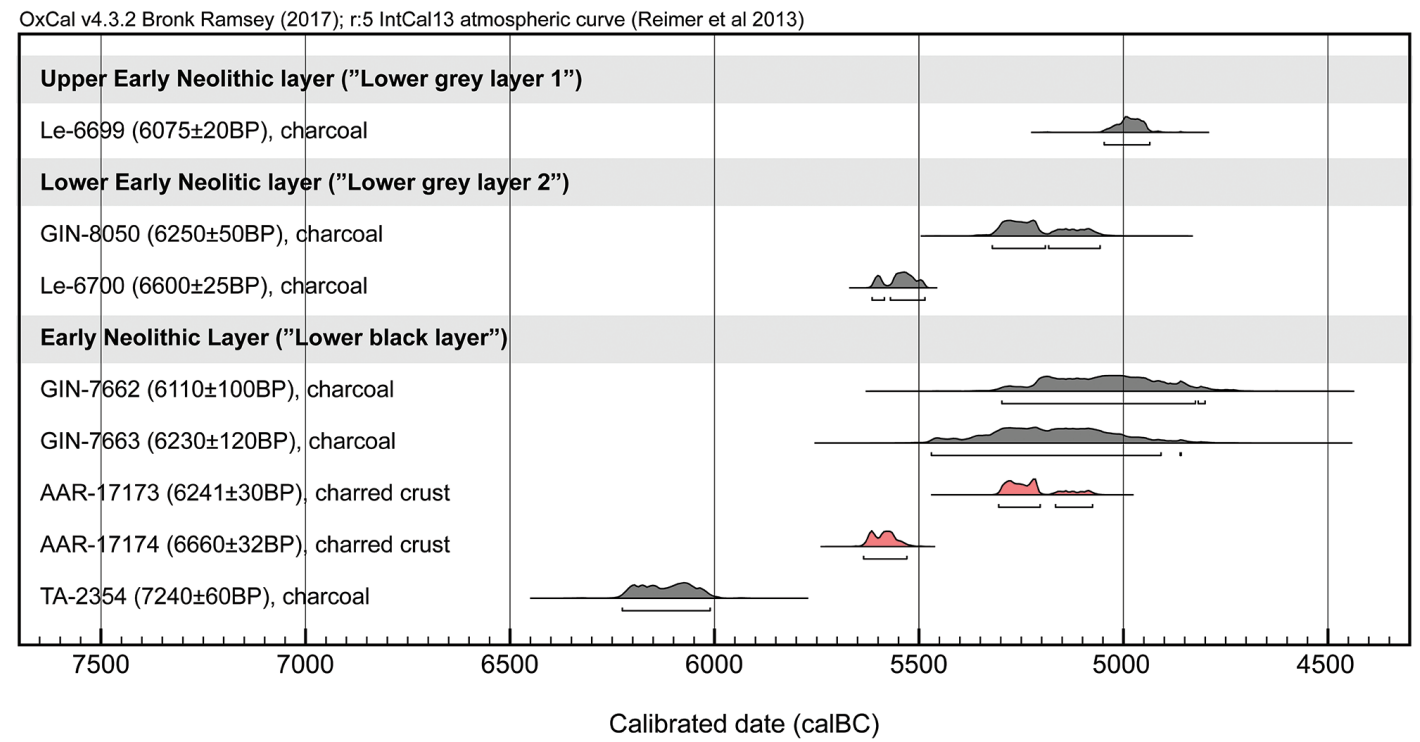

Fig. 19. Tudozero 5, Vologda province, Russia. Calibrated ${ }^{14} \mathrm{C}$ dates from the Early Neolithic layers. Grey - charcoal; red - charred crust.

It is not clear whether a freshwater reservoir effect might have influenced this date. A charcoal sample from the Lyalovo layer excavated in a new test trench at Veksa 1 in 2016 provided a somewhat younger age, in the third quarter of the $6^{\text {th }}$ millennium. Two dates on a stray find vessel from Veksa 3 which typologically resembles Narva pottery also lie in the $3^{\text {rd }}$ quarter of the $5^{\text {th }}$ millennium cal BC; here, too, reservoir effects might play a role and the actual date of the vessel could be younger.

The ${ }^{14} \mathrm{C}$ age of the food crust on the Kargopol culture sherd from Karavaikha 1 (AAR-17169, 5588 \pm 32 $\mathrm{BP})$ is in broad accordance with its expected position in the early phase of this Middle Neolithic culture, although the contextual and typological information on chronology is in this case not detailed enough to decide whether a FRE might have affected the date or not.

\section{Conclusions and perspectives}

The radiocarbon dating evidence of the Early and Middle Neolithic between the Sukhona and southern Onega regions of northern Russia has been expanded in recent years by a number of AMS dates, and today, almost 80 dates exist for the four key archaeological localities of Berezovaya Slobodka, Veksa, Karavaikha and Tudozero. These data help to understand the onset and initial development of ceramic production more precisely (the main criterion for the Neolithic in this region), and the cultural developments among the pottery-producing hunter-gatherer-fisher groups in these northern areas far be- yond the world of the agricultural Neolithic farther south and west.

While our knowledge of the absolute chronology of these processes has greatly advanced with the increasing number of radiocarbon dates, a number of obstacles remain concerning the reliability both of the dates themselves, and of the archaeological context that they are dating. Dates on pottery food crusts appear to have been distorted by freshwater reservoir effects in some cases, resulting in dates that can be centuries too old. To build better chronologies from food crust dates, we need to determine which ${ }^{14} \mathrm{C}$ results are potentially subject to freshwater reservoir effects, i.e. to distinguish crusts derived mainly from aquatic ingredients from those composed mainly of terrestrial foods. Integrating laboratory analyses with relative chronologies based on typology and stratigraphy, but also by determining local aquatic reservoir ages can help to assess the extent of freshwater reservoir effects on food-crust dates. To understand the potential variability in food-crust freshwater reservoir effects, we also need to date multiple fish remains from closely dated contexts.

The examples of the four localities presented here also show that another problem concerns the ultimately unreliable association between the dated context samples and the early pottery phase. Are the most ancient dates from the horizons regarded as Early Neolithic really already associated with the early pottery phase at Berezovaya Slobodka, or at Karavaikha 4? Does the earliest anthropogenic lens at Veksa 3, test trench 1, belong to the pre-pottery 
period, or is it merely coincidental that no fragment of the new material (which was still rare initially) has been left or lost in this activity zone?

While many of the radiocarbon results are consistent with stratigraphies and expected typological sequences, several charcoal dates from Berezovaya Slobodka by the River Sukhona and from Tudozero on the southern end of Lake Onega that are stratigraphically associated with Early Neolithic horizons appear rather old, dating to the end of the $7^{\text {th }}$ millennium cal BC. Further investigations are needed to follow up the question of whether in these northern regions sparsely decorated, flat-based wares appeared more or less contemporaneously with the typologically connected Early Upper Volga culture pottery several hundred kilometres farther south, which is thought to begin in the early $6^{\text {th }}$ millennium cal BC (Hartz et al. 2012). Likewise, the phenomenon of a pre-Sperrings Comb ware, its typological origins and links and its chronological position need to be further investigated. Only on the basis of a reliable chronology will it be possible to better understand the cultural processes, regional and supra-regional interactions in the early to mid-Holocene that are reflected in various early pottery types and that later led to the formation of larger typological units, including Typical Comb Ware and Pit-Comb Wares at the onset of the Middle Neolithic period in northeastern Europe in the $5^{\text {th }}$ millennium cal BC.

\section{ACKNOWLEDGEMENTS}

Radiocarbon measurements of modern fish were funded by the Centre for Baltic and Scandinavian Archaeology, Schloss Gottorf, Germany, under its Man and Environment research theme. The extraction and determination of the charred plant remains from Veksa 3, test trench 1, were conducted by Wiebke Kirleis and Vanessa Elberfeld, Kiel University, Germany.

\section{$\therefore$}

\section{References}

Brysov A. Ya. 1951. Svajnoe poselenie na reke Modlone i drugie stoyanki v Charozerskom rayone Vologdskoi oblasti. Materialy $i$ issledovaniya po arkheologii 20: 7-76. (in Russian)

1961. Karavaevskaya stoyanka. Sbornik po arkheologii Vologodskoj oblasti: 72-162. (in Russian)

Chairkina N. M., Kosinskaya L. 2009. Early hunter-gatherer ceramics in the Urals and Western Siberia. In P. Jordan, M. Zvelebil (eds.), Ceramics before Farming. The dispersal of pottery among prehistoric Eurasian hunter-gatherers. Left Coast Press. Walnut Creek: 209-235.

Filatova V. F. 2006. Voprosy proiskhozhdenija i etnokulturnoi prinadlezhnosti naseleniya epokhi mezolita (Questions of the emergence and ethnocultural position of the population of the Mesolithic period). In S. I. Kochkurkina, M. G. Kosmenko (eds.), Problemy etnokulturnoi istorii naseleniya Karelii (mezolit-srednevekove) (Problems of the ethno-cultural history of the Population of Karelia). Petrozavodsk: 14-72. (in Russian)

Fischer A., Heinemeier J. 2003. Freshwater reservoir effect in ${ }^{14} \mathrm{C}$ dates of food residue on pottery. Radiocarbon 45 (3): 449-466.

Hammer S., Levin, I. 2017. Monthly mean atmospheric D14C02 at Jungfraujoch and Schauinsland from 1986 to
2016. heiDATA Dataverse. http://dx.doi.org/10.11588/ data $/ 10100$

Hartz S., Kostyleva E., Piezonka H., Terberger T., Tsydenova N. and Zhilin M. G. 2012. Hunter-gatherer pottery and charred residue dating: new results on early ceramics in the north Eurasian forest zone. Radiocarbon 54(3-4): 1033-1048.

Heron C., Craig 0. E. 2015. Aquatic resources in foodcrusts: identification and implication. Radiocarbon 57(4): 707-719.

Ivanishchev A. M., Ivanishcheva M. V. 2000. Tudozero-V poselenie pozdnego mezolita - rannego neolita $v$ Yuzhnom Prionezh'e (Tudozero-V, a settlement of the late Mesolithic-early Neolithic in the south Onega region). Tverskoi Arkheologicheski Sbornik 4(1): 284-296. (in Russian)

Ivanishcheva M. V. 2009. Kompleksy s tychkogo-nakol'chatoj keramikoj v Nizhnem Posukhon'e. Isvestiya Samarskogo nauchnogo centra Rossiyskoy Akadimii Nauk 11 (9): 277-281. (in Russian)

2014. Ranneneoliticheskie pamjatniki Yugo-Vostochnogo Prionezh'ya. Isvestiya Samarskogo nauchnogo centra Rossiyskoy Akadimii Nauk 16(3): 255-259. (in Russian) 
2015. 0 rybolovstve v kamennom veke i Srednevekov'e na Tudozere. In N. G. Zaitseva, E. V. Zakharova et al. (eds.), Materialy nauchnoj konferencii "Bubrikhovskie shteniya: gumnitarnye nauki na Evropeiskom Severe" $v$ g. Petrozavaodsk 1-2 oktyabrya 2015 goda. Petrozavodsk: 33-42. (in Russian)

Ivanishcheva M. V., Ivanishchev A. M. 2006. Poselenie rannego neolita na Nizhnei Sukhone. Tverskoi Arkheologicheski Sbornik 6(1): 287-299. (in Russian)

Ivanishcheva M. V., Kulkova M. A. and Ivanishcheva E. A. 2016. Radiocarbon chronology of the Early Neolithic in the Low Sukhona River and south-eastern Onega Lake. In G. V. Zaitseva, O. V. Lozovskaya, A. A. Vybornov and A. N. Mazurkevich (eds.), Radiouglerodnaya khronologiya epokhi neolita Vostochnoi Evropy VII-III tysjacheletiya do $n$. e. Svitok. Smolensk: 397-409. (in Russian)

Ivanishcheva M. V., Kulkova M. A. and Sapelko T. V. 2015. Natural processes in Holocene in the South Onega Lake region (on the basis of complex studies of multilayer settlement Tudozero V). In V. M. Lozovskii, O. V. Lozovskaya and A. A. Vybornov (eds.), Neolithic Cultures of Eastern Europe: Chronology, paleoecology and cultural traditions. Materials of the international conference dedicated to the $7^{\text {th }}$ anniversary of Viktor Petrovich Tretyakov. May, 12-16. Rossiyskaya Akademya Nauk; Institut istorii materialnoy kulturi; Gosudarstvenniy Ermitazh; Povolzhaya gosudarstvennaya socialno-gumanitarnaya akadeiya; Muzei antropologii i etnografii im. Petra Velikogo (Kunstkamera). Sankt-Peterburg: 285-289.

Karmanov V. N., Zaretskaya N. E. and Volokitin A. V. 2014. Another way of early pottery distribution in eastern Europe? Case study of the Pezmog 4 site, European far northeast. Radiocarbon 56(2): 733-741.

Kiryanova A. V., Kosorukova N. V. 2013. K voprosu o datirovke torfyanikovoi stoyanki Karavaikha $4 \mathrm{v}$ basseine ozera Vozhe [On the question of the dating of the peatbog site of Karavaikha 4 in Lake Vozhe basin]. In Geologo-Arkheologicheskie issledovaniya $v$ timano-severouralskom regione. Doklady 16-i nauchnoi konferencii 31 oktyabrya 2013 g. Syktyvkar: 105-111. (in Russian)

Kosorukova N. V. 2007. Perekhod ot mezolita k neolitu v bassejne ozera Vozhe (novye materialy) [The transition from the Mesolithic to the Neolithic in the basin of Lake Vozhe (new materials)]. In Russkaya kultura novogo stoletiya: problemy izucheniya, sokhraneniya I ispolzovaniya istoriko-kulturnogo naslediya. Sbornik statei. Knizhnoe nasledie. Vologda: 41-52. (in Russian)

2008. Issledovanie ranneneoliticheskogo poseleniya Karavaikha $4 \mathrm{v}$ bassejne ozera Vozhe v $2007 \mathrm{~g}$. In Russkii Sever: variativnost" razvitiya $v$ kontekste istoriches- kogo i social'no-filozoficheskogo osmysleniya. Vologda: 13-20. (in Russian)

2014. 0 datirovka torfianikovoi stoyanki Karavaikha 4 v basseine ozera Vozhe. In Ot Baltiki do Urala: izykaniya po arkheologii kamennogo veka. Syktyvkar: 142146. (in Russian)

Kosorukova N. V., Piezonka H. 2014. Novye materialy po epokhe neolita $\mathrm{v}$ basseine ozera Vozhe. In A. N. Mazurkevich, M. E. Polkovnikova and E. V. Dolbunova (eds.), $A r$ kheologiya ozernykh poselenii IV-II tys. do n. e.: Khronologiya kul'tur i prirodno-klimaticheskie ritmy. Periferiya. Sankt-Peterburg: 169-174. (in Russian)

Kosorukova N. V, Venediktova N. N. 2014. Rybolovnyi promysel u naceleniya stoyanki Karavaikha 4. Arkheologiya Severa 5: 30-41. (in Russian)

Kosorukova N. V., Kulkova M. A., Piezonka H., Nesterova L. A., Sementsov A. A., Lebedeva L. M., Hartz S. and Terberger T. 2016. Radiocarbon dating of Neolithic sites at Karavaikha in the Vozhe lake basin. In G. V. Zaitseva, 0. V. Lozovskaya, A. A. Vybornov and A. N. Mazurkevich (eds.), Radiouglerodnaya khronologiya epokhi neolita Vostochnoi Evropy VII-III tysjacheletiya do n. e. Svitok. Smolensk: 410-424.

Kulkova M. A., Ivanishcheva M. V. and Soldatenkova A. D. 2014. Geoekologiya pamyatnika epokhi kamennogo veka - srednevekov'ya Tudozero V po dannym geokhimicheskikh issledovanii. In E. M. Nesterova, V. A. Snytko (eds.), Geologiya, geoekologiya, evolyutsionnaya geografiya: Kollektivnaya monografiya. Tom XIII. Izdatel'stvo RGPY im. A. I. Gertsena. Sankt-Peterburg: 193-198. (in Russian)

Lorenz S., Nedomolkina N. G. and Piezonka H. 2012. Geoarchaeology and floodplain development at the outstanding multiperiod dwelling site of Veksa in the Sukhona basin. In A. I. Zhirob, V. Yu. Kuznecov, D. A. Subetto and I. Tide (eds.), Geomorfologiya i Paleogeografiya Polyarnykh Regionov: Materialy sovmestnoi mezhdunarodnoi konferencii "Geomorphologiya i Paleogeografiya Polyarnykh Regionov", simposiuma "Leopoldina" $i$ soveshchaniya rabochei gruppy INQUA Peribaltic, Sankt-Peterburg. SPbGU, 9-17 sentyabrya 2012 goda. Sankt-Peterburg: 467-468.

Mazurkevich A. N., Dolbunova E. V. 2015. The oldest pottery in hunter-gatherer communities and models of Neolithisation of Eastern Europe. Documenta Praehistorica 42: $13-66$.

Meadows J., Lozovski V. M., Lozovskaya O. V., Lübke H., Zaitseva G. I. and Kulkova M. A. 2015. Place of Zamostje 2 site pottery assemblage within the overall chronology of Upper Volga-type pottery. In V. M. Lozovski, O. V. Lo- 
zovskaya and A. A. Vybornov (eds.), Neolithic Cultures of Eastern Europe: Chronology, Paleoecology and Cultural Traditions. Materials of the international conference dedicated to the $75^{\text {th }}$ anniversary of Victor Petrovich Tretyakov, May, 12-16, 2015, St. Petersburg. Sankt-Peterburg: 84-91.

Nedomokina N. G. 2000. Mnogosloynoe poselenie Veksa. Tverskoi Arkheologicheski Sbornik 4(1): 277-283. (in Russian)

2004. Neoliticheskie kompleksy poselenii Veksa, Veksa III basseina Verkhnei Sukhony i ikh khronologiya [Neolithic complexes of the settlements Veksa, Veksa III of the Upper Sukhona basin and their chronology]. In Problemy khronologiya i etnokulturnykh vsaimodeistvii $v$ neolite Evrazii [Problems of chronology and ethnocultural interrelations in the Neolithic of Eurasia], vol. 2. Sankt-Peterburg: 265-279.

Nedomolkina N. G., Ivanishcheva M. V. 2014. Bassein Sukhony $\mathrm{v}$ razvitom neolite. In Uchenye zapiski Petrozavodskogo gosudarstvennogo universiteta. Seriya; obshchestvennye I gumanitarnye nauki 1 (146). Karelskiy Nauchniy Centr Rossiyskoy Akadimii Nauk. Petrozavodsk: 12-18. (in Russian)

Nedomolkina N. G., Piezonka H. 2016. Radiocarbon chronology of the Upper Sukhona Region in Early and Middle Neolithic (sites Veksa I and Veksa III). In G. V. Zaitseva, O. V. Lozovskaya, A. A. Vybornov and A. N. Mazurkevich (eds.), Radiouglerodnaya khronologiya epokhi neolita Vostochnoi Evropy VII-III tysjacheletiya do n. e. Svitok. Smolensk: 425-433.

Nedomolkina N. G., Piezonka H. 2017. Results on absolute and relative chronology based on materials from the multi-layered settlement site of Veksa 3. In A. A. Vybronov, A. N. Mazurkevich, E. V. Dolbunova and E. S. Tkach (eds.), Cultural Processes in the Circum-Baltic Space in the Early and Middle Holocene. Papers of the international scientific conference dedicated to the memory of Vladimir I. Timofeev. Saint-Petersburg, Russia, April 26-28, 2017. Muzei antropologii i etnografii im. Petra Velikogo (Kunstkamera) Rossiyskoy Akademi Nauk; Institut istorii materialnoy kulturi Rossiyskoy Akademi Nauk; Gosudarstvenniy Ermitazh; Samarskiy gosudarstvenniy socialno-pedagogicheskiy universitet. Sankt-Peterburg: 119-123.

Nedomolkina N. G., Piezonka H., Meadows J., Craig O. and Lorenz S. 2015. Neoliticheskie kompleksy poseleniya Veksa v basseine Verkhnej Sukhony, Severo-Zapadnaya Rossiya: novye estestvennonauchnye issledovaniya. In V. M. Lozovskii, 0. V. Lozovskaya and A. A. Vybornov (eds.), Neolithic Cultures of Eastern Europe: Chronology, paleoecology and cultural traditions. Materials of the international conference dedicated to the 75th anniversary of
Viktor Petrovich Tretyakov. May, 12-16, 2015. Rossiyskaya Akademya Nauk; Institut istorii materialnoy kulturi; Gosudarstvenniy Ermitazh; Povolzhaya gosudarstvennaya socialno-gumanitarnaya akadeiya; Muzei antropologii i etnografii im. Petra Velikogo (Kunstkamera). SanktPeterburg: 151-159. (in Russian)

Lozovskii V. M., Lozovskaya 0. V. and Vybornov A. A. (eds.) 2015. Neolithic Cultures of Eastern Europe: Chronology, paleoecology and cultural traditions. Materials of the international conference dedicated to the $7^{\text {th }}$ anniversary of Viktor Petrovich Tretyakov. May, 12-16, 2015. Rossiyskaya Akademya Nauk; Institut istorii materialnoy kulturi; Gosudarstvenniy Ermitazh; Povolzhaya gosudarstvennaya socialno-gumanitarnaya akadeiya; $\mathrm{Mu}$ zei antropologii i etnografii im. Petra Velikogo (Kunstkamera). Sankt-Peterburg.

Nordqvist K., Mökkönen, T. 2016. New radiocarbon dates for early pottery in north-eastern Europe. In 0. V. Lozovskaya, A. N. Mazurkevich and E. V. Dolbunova (eds.), Tradicii i innovacii v izuchenii drevneishej keramiki. Materialy mezhdunarodnoy konferentsii 24-27 maya 2016 goda, Sankt-Peterburg, Rossiya. Sankt-Peterburg: 204-214.

Oshibkina S. (ed.) 1996. Neolit Severnoi Evrazii. Nauka. Moskva. (in Russian)

Oshibkina S. V. 2006. To the question of the Neolithic revolution and the Neolithization of the forest zone of Eurasia. In L. N. Koryakova, P. Y. Pavlov., V. N. Shirokov and A. A. Shorin (eds.), II Northern Archaeological Congress. Papers. September 24-30, 2006, Khanty-Mansiisk. Charoid. Ekaterinburg: 262-279.

Piezonka H. 2008. Neue AMS-Daten zur frühneolithischen Keramikentwicklung in der nordosteuropäischen Waldzone. Estonian Journal of Archaeology 12(2): 67-113.

2015. Jäger, Fischer, Töpfer. Wildbeutergruppen mit früher Keramik in Nordosteuropa im 6. und 5. Jahrtausend v. Chr. Archäologie in Eurasien 30. Habelt Kommissions. Bonn.

2017. Mesolithic - Subneolithic - Neolithic: The problem of defining Neolithization between East and West. In A. A. Vybronov, A. N. Mazurkevich, E. V. Dolbunova and E. S. Tkach (eds.), Cultural Processes in the Circum-Baltic Space in the Early and Middle Holocene. Papers of the international scientific conference dedicated to the memory of Vladimir I. Timofeev. SaintPetersburg, Russia, April 26-28, 2017. Muzei antropologii i etnografii im. Petra Velikogo (Kunstkamera) Rossiyskoy Akademi Nauk; Institut istorii materialnoy kulturi Rossiyskoy Akademi Nauk; Gosudarstvenniy Ermitazh; Samarskiy gosudarstvenniy socialno-pedagogicheskiy universitet. Sankt-Peterburg: 97-103. 
Piezonka H., Meadows J., Hartz S., Kostyleva E., Nedomolkina N., Ivanishcheva M., Kozorukova N. and Terberger T., 2016. Stone Age pottery chronology in the northeast European forest zone: New AMS and EA-IRMS results on foodcrusts. Radiocarbon 58(2): 267-289.

Timofeev V. I., Zaitseva G. I., Dolukhanov P. M. and Shukurov A. M. 2004. Radiouglerodnaya khronologija neolita Severnoi Evrazii. Teza. Sankt-Peterburg. (in Russian)

Utkin A. V., Kostyleva E. L. 2001. Pogrebeniya na stoyanke Karavaikha [Burials at the site of Karavaikha]. Rossijskaya Arkheologiya 3: 55-66. (in Russian)

Wood R. E., Higham T. F. G., Buzilhova A., Suvorov A., Heinemeier J. and Olsen J. 2013. Freshwater radiocarbon re- servoir effects at the burial ground of Minino, northwest Russia. Radiocarbon 55(1): 163-177.

Zajtseva G. V., Lozovskaya 0. V., Vybornov A. A. and Mazurkevich A. N. (eds.) 2016. Radiouglerodnaya khronologiya epokhi neolita Vostochnoi Evropy VII-III tysjacheletiya do n. e. Svitok. Smolensk. (in Russian)

Zaitseva G. I., Skakovskii E. D., Sementsov A. A., Lebedeva L. M. and Burova N. D. 2016. Chemical composition of carbon-contained components in Neolithic pottery. In G. V. Zaitseva, 0. V. Lozovskaya, A. A. Vybornov and A. N. Mazurkevich (eds.), Radiouglerodnaya khronologiya epokhi neolita Vostochnoi Evropy VII-III tysjacheletiya do n. e. Svitok. Smolensk: 32-37. 
Tab. 1. Radiocarbon dating results on organic material from

\begin{tabular}{|c|c|c|c|}
\hline Site & Context & $\begin{array}{l}\text { Chrono- } \\
\text { typological } \\
\text { association }\end{array}$ & Material \\
\hline $\begin{array}{l}\text { Beresovaya } \\
\text { Slobodka II-III }\end{array}$ & $\begin{array}{l}\text { Trench 7, 2002, squ. C-2, }-92 \text {, depth } 140 \mathrm{~cm} \text {, dark sandy loam, Early Neolithic, } \\
\text { layer 2, from a fireplace, close to flat-based ceramic vessel with pin-point decoration }\end{array}$ & $\begin{array}{c}\text { Early } \\
\text { Neolithic }\end{array}$ & charcoal \\
\hline $\begin{array}{l}\text { Beresovaya } \\
\text { Slobodka II-III }\end{array}$ & $\begin{array}{l}\text { Trench 7, 2002, squ. C-2, }-87 \text {, depth } 165 \mathrm{~cm} \text {, dark sandy loam, Early Neolithic, } \\
\text { layer 2, close to flat-based ceramic vessel with pin-point decoration }\end{array}$ & $\begin{array}{c}\text { Early } \\
\text { Neolithic }\end{array}$ & charcoal \\
\hline $\begin{array}{l}\text { Beresovaya } \\
\text { Slobodka II-III }\end{array}$ & $\begin{array}{l}\text { Trench 6, 2004, squ. P-4, +34, depth } 40 \mathrm{~cm} \text {, dark sandy loam, Early Neolithic layer, } \\
\text { fragment of undecorated, grog-tempered vessel }\end{array}$ & $\begin{array}{c}\text { Early } \\
\text { Neolithic }\end{array}$ & pottery \\
\hline $\begin{array}{l}\text { Beresovaya } \\
\text { Slobodka VI }\end{array}$ & $\begin{array}{l}\text { Trench 2, } 2007 \text {, squ. Z-9, }-37-41 \text {, depth } 20 \mathrm{~cm} \text {, yellow sandy loam, Early Neolithic } \\
\text { layer, depth } 40 \mathrm{~cm} \text {, dark sandy loam, Early Neolithic layer, accumulation on thick } \\
\text { wall fragment of pin-point decorated, grog-tempered vessel }\end{array}$ & $\begin{array}{l}\text { Early } \\
\text { Neolithic }\end{array}$ & pottery \\
\hline Karavaikha 1 & $\begin{array}{l}\text { 2002, test trench 1, peaty depression, pit-decorated pot sherd (find no. 3942) } \\
\text { from gyttia layer }\end{array}$ & $\begin{array}{l}\text { Middle Neolithic } \\
\text { (Kargopol') }\end{array}$ & foodcrust \\
\hline Karavaikha 4 & $\begin{array}{l}2014 \text {, trench } 14 \text {, squ. E- } 6 \text {, fragment of wooden pile beaten into the clay subsoil } \\
\text { in wall of depression no. } 2 \text { with fishing constructions }\end{array}$ & $\begin{array}{l}\text { Late Mesolithic or } \\
\text { Early Neolithic (?) }\end{array}$ & wood \\
\hline Karavaikha 4 & $\begin{array}{l}2011 \text {, trench 12, squ. P-7, fragment of wooden pile beaten deep into the clay } \\
\text { subsoil beyond the depressions, south of depression no. } 2\end{array}$ & $\begin{array}{l}\text { Late Mesolithic or } \\
\text { Early Neolithic (?) }\end{array}$ & wood \\
\hline Karavaikha 4 & $\begin{array}{l}\text { 2012, trench 15, squ. G-19, fragment of relatively short wooden pile beaten } \\
\text { into clay subsoil far from the riverbank, to the west of the depressions }\end{array}$ & $\begin{array}{l}\text { Late Mesolithic or } \\
\text { Early Neolithic (?) }\end{array}$ & wood \\
\hline Karavaikha 4 & $\begin{array}{l}2012 \text {, trench } 15 \text {, squ. JA-19, flat wide thin board in the lowest part of the gyttja } \\
\text { at its contact zone with the subsoil below (peaty loamy clay) }\end{array}$ & $\begin{array}{l}\text { Late Mesolithic or } \\
\text { Early Neolithic (?) }\end{array}$ & wood \\
\hline Karavaikha 4 & $\begin{array}{l}\text { 2004, trench 2, squ. P-11, wooden artefact in the lower part of the gyttia, } \\
\text { above the main level of artefacts }\end{array}$ & $\begin{array}{l}\text { Late Mesolithic or } \\
\text { Early Neolithic (?) }\end{array}$ & wood \\
\hline Karavaikha 4 & $\begin{array}{l}\text { 2004, trench } 3 \text {, fragment of woden pile beaten into the clay subsoil close to the } \\
\text { edge of depression with fishing constructions }\end{array}$ & $\begin{array}{l}\text { Late Mesolithic or } \\
\text { Early Neolithic (?) }\end{array}$ & wood \\
\hline Karavaikha 4 & $\begin{array}{l}2005 \text {, trench } 5 \text {, squ. F-10, horizon } 8 \text {, fragment of bone tool with asymmetrical } \\
\text { point, at the contact between gyttja and clay subsoil }\end{array}$ & $\begin{array}{l}\text { Late Mesolithic or } \\
\text { Early Neolithic (?) }\end{array}$ & $\begin{array}{l}\text { bone } \\
\text { (indeter- } \\
\text { minate } \\
\text { ungulate) }\end{array}$ \\
\hline Karavaikha 4 & $\begin{array}{l}2011 \text {, trench } 12 \text {, squ. X-6, fragment of wooden pile beaten into the clay subsoil } \\
\text { south of depression no. } 2 \text {, not far from its edge }\end{array}$ & $\begin{array}{l}\text { Late Mesolithic or } \\
\text { Early Neolithic (?) }\end{array}$ & wood \\
\hline Karavaikha 4 & $\begin{array}{l}2014 \text {, trench } 16 \text {, squ. Š- } 6 \text {, wooden board beaten either vertically or at an angle } \\
\text { into the clay subsoil at the edge of depression no. } 2 \text {, part of a fishing construction }\end{array}$ & $\begin{array}{l}\text { Late Mesolithic or } \\
\text { Early Neolithic (?) }\end{array}$ & wood \\
\hline Karavaikha 4 & $\begin{array}{l}2014 \text {, trench } 16 \text {, squ. E- } 6 \text {, long wooden board, placed at an angle on the clay } \\
\text { subsoil at the edge of depression no. } 2 \text { with fishing constructions }\end{array}$ & $\begin{array}{l}\text { Late Mesolithic or } \\
\text { Early Neolithic (?) }\end{array}$ & wood \\
\hline Karavaikha 4 & $\begin{array}{l}2004 \text {, trench 1, depression no. 1, wooden artefact in the upper part of sand layer } \\
\text { which lay between gyttja and clay subsoil }\end{array}$ & $\begin{array}{l}\text { Late Mesolithic or } \\
\text { Early Neolithic (?) }\end{array}$ & wood \\
\hline Karavaikha 4 & $\begin{array}{l}\text { 2004, trench 1, squ. P-22, wooden artefact in the lower part of } \\
\text { the gyttja layer }\end{array}$ & $\begin{array}{l}\text { Late Mesolithic or } \\
\text { Early Neolithic (?) }\end{array}$ & wood \\
\hline Karavaikha 4 & $\begin{array}{l}2011, \text { trench } 12, \text { squ. } X-7 \text {, fragment } f \text { wooden pile beaten into clay subsoil } \\
\text { at the sloping edge of depression no. } 2\end{array}$ & $\begin{array}{c}\text { Mesolithic or } \\
\text { Early Neolithic (?) }\end{array}$ & wood \\
\hline Karavaikha 4 & $\begin{array}{l}\text { 2004, trench 2, depression no. 2, wooden artefact in the upper part of the sand } \\
\text { layer which lay between the gyttja and the clay subsoil }\end{array}$ & $\begin{array}{c}\text { Mesolithic or } \\
\text { Early Neolithic (?) }\end{array}$ & wood \\
\hline Karavaikha 4 & $\begin{array}{l}2014 \text {, trench } 16 \text {, squ. B-6, long wooden beam that lay at an angle at the edge } \\
\text { of depression no. } 2\end{array}$ & $\begin{array}{c}\text { Mesolithic or } \\
\text { Early Neolithic (?) }\end{array}$ & wood \\
\hline Karavaikha 4 & 2004 , trench 2, depression no. 2, wooden pile beaten into the clay subsoil & $\begin{array}{c}\text { Mesolithic or } \\
\text { Early Neolithic (?) }\end{array}$ & wood \\
\hline Karavaikha 4 & $\begin{array}{l}\text { Charred crust combined from three fragments of pottery probably belonging to } \\
\text { one vessel with comb ornament: 1) } 2006 \text {, trench } 7 \text {, squ. C- } 25 \text {, lower part of dark } \\
\text { green peaty gyttja under concentration of wood, } 15 \mathrm{~cm} \text { above main level of } \\
\text { artefacts; 2) 2004, trench 1, squ. P-25, in lower part of gyttja } 35 \mathrm{~cm} \text { above main } \\
\text { level of artefacts; 3) } 2003 \text {, trench 1, squ. P23, in lower part of gyttja } 35 \mathrm{~cm} \text { above } \\
\text { main level of artefacts }\end{array}$ & $\begin{array}{l}\text { Early } \\
\text { Neolithic }\end{array}$ & foodcrust \\
\hline Karavaikha 4 & Trench 1, fragment of wooden beam from gyttja above main level of artefacts & Early Neolithic & wood \\
\hline Karavaikha 4 & 2004 , trench 1, squ. C22, wooden artefact lying in gyttja above main level of artefacts & Early Neolithic & wood \\
\hline Karavaikha 4 & $\begin{array}{l}\text { 2012, trench 15, squ. B20, wooden lath from accumulation of small wooden } \\
\text { laths lying at the contacts zone between gyttia and clay subsoil }\end{array}$ & $\begin{array}{l}\text { Early } \\
\text { Neolithic }\end{array}$ & wood \\
\hline
\end{tabular}


The Early and Middle Neolithic in NW Russia: Radiocarbon chronologies from the Sukhona and Onega regions

\section{Early and Middle Neolithic complexes in northwest Russia.}

\begin{tabular}{|c|c|c|c|c|c|c|c|c|c|}
\hline Lab. No. & $\begin{array}{l}\text { Yield } \\
(\%)^{*}\end{array}$ & $\% \mathrm{CJ}$ & $\% \mathrm{NJ}$ & $\begin{array}{c}\text { atomic } \\
\mathrm{C} / \mathrm{N}\end{array}$ & $\begin{array}{l}\delta 13 C \\
(\% \circ) \int\end{array}$ & $\begin{array}{l}\delta 15 N \\
(\% \circ) \int\end{array}$ & $\begin{array}{l}\text { Conventional } \\
14 \mathrm{C} \text { age } \mathrm{BP} *\end{array}$ & $\begin{array}{l}\text { Maximum age } \\
\text { cal BC \ }(95,4 \\
\% \text { probability) }\end{array}$ & Reference \\
\hline Le-6713 & & & & & & & $7340 \pm 200$ & $6600-5810$ & Ivanishcheva 2006 \\
\hline Le-6707 & & & & & & & $7340 \pm 90$ & $6400-6030$ & Ivanishcheva 2009 \\
\hline Ki- 16392a & & & & & & & $6210 \pm 80$ & $5340-4950$ & Ivanishcheva 2009 \\
\hline Ki- 16392 & & & & & & & $5850 \pm 80$ & $4930-4520$ & Ivanishcheva 2009 \\
\hline $\begin{array}{l}\text { AAR- } \\
17169\end{array}$ & & 16.4 & 3.5 & 5.5 & -27.90 & 9.75 & $5588 \pm 32$ & $4490-4350$ & Piezonka et al. 2016 \\
\hline Le-10766 & & & & & & & $7190 \pm 160$ & $6390-5760$ & Kosorukova et al. 2016 \\
\hline Le-10773 & & & & & & & $7130 \pm 50$ & $6080-5900$ & Kosorukova et al. 2016 \\
\hline Le-10770 & & & & & & & $7100 \pm 60$ & $6070-5850$ & Kosorukova et al. 2016 \\
\hline Spb-1300 & & & & & & & $7050 \pm 80$ & $6060-5760$ & Kosorukova et al. 2016 \\
\hline Le-7191 & & & & & & & $7030 \pm 60$ & $6020-5770$ & Kosorukova et al. 2016 \\
\hline Le-7190 & & & & & & & $7015 \pm 35$ & $5990-5810$ & Kosorukova et al. 2016 \\
\hline $\begin{array}{l}\text { AAR- } \\
17170\end{array}$ & & & & 3.2 & -21.72 & 4.6 & $7009 \pm 40$ & $5990-5790$ & Kosorukova et al. 2016 \\
\hline
\end{tabular}

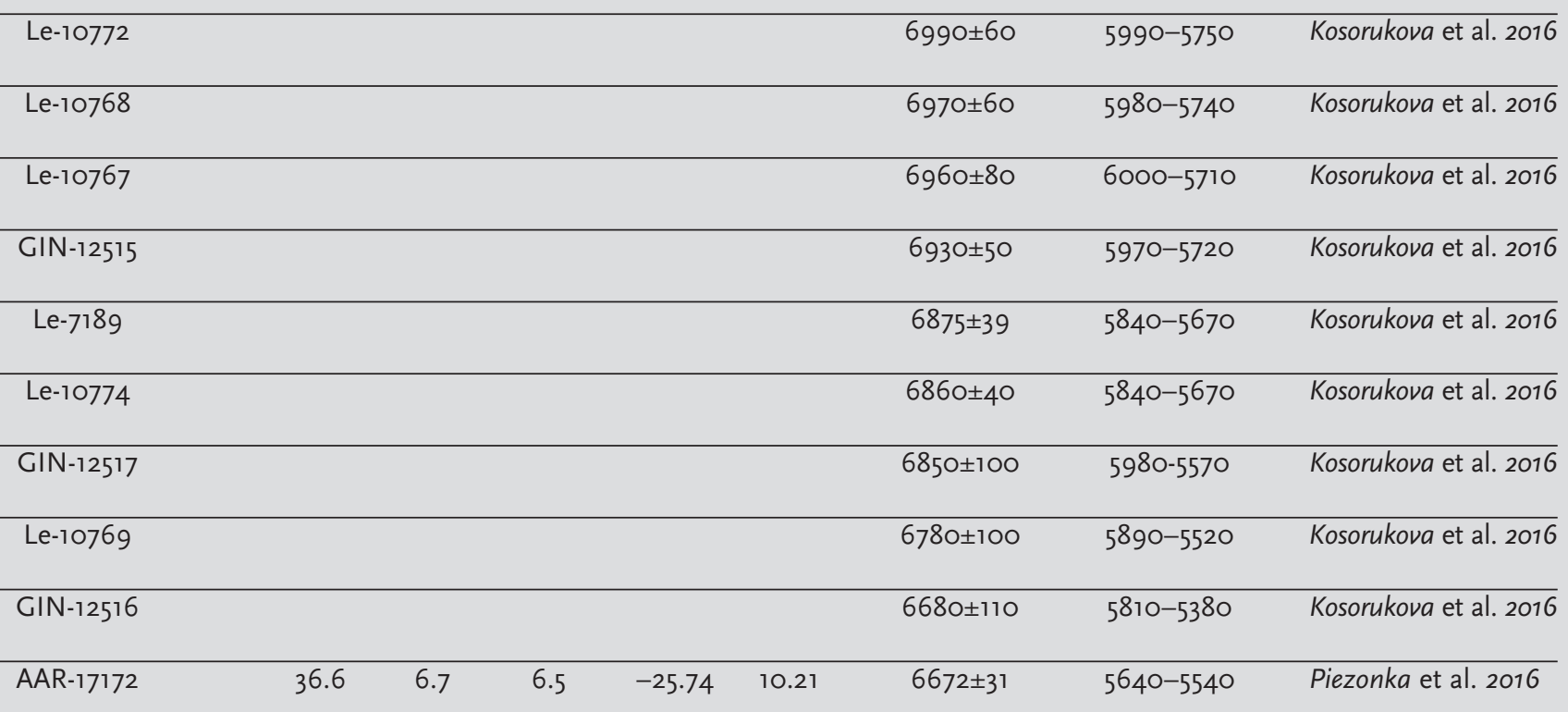

\begin{tabular}{cccc} 
GIN-12513 & $6670 \pm 50$ & $5670-5490$ & Kosorukova et al. 2016 \\
\hline Le-7192 & $6540 \pm 150$ & $5750-5210$ & Kosorukova et al. 2016 \\
\hline SPb-1301 & $6533 \pm 80$ & $5630-5340$ & Kosorukova et al. 2016
\end{tabular}




\begin{tabular}{|c|c|c|c|}
\hline Site & Context & $\begin{array}{l}\text { Chrono- } \\
\text { typological } \\
\text { association }\end{array}$ & Material \\
\hline Karavaikha 4 & 2007, trench 8, wooden object from lower part of gyttia & Early Neolithic & wood \\
\hline Karavaikha 4 & $\begin{array}{l}\text { 2004, trench 1, squ. P2, short wooden pile beaten into the clay subsoil south of } \\
\text { depression no. } 2\end{array}$ & Early Neolithic & wood \\
\hline Karavaikha 4 & $\begin{array}{l}\text { Charred crust combined from three fragments of pottery probably belonging to } \\
\text { one vessel with impressed decoration by natural stamps: 1) } 2007 \text {, trench } 8 \text {, squ. } \\
\text { O19, horizon } 5 \text {, from lower part of gyttja; 2) } 2004 \text {, trench } 1, \text { squ. C22, from lower } \\
\text { part of gyttja } 25 \mathrm{~cm} \text { above main level of artefacts; } 3 \text { ) 2005, trench } 6 \text {, squ. O23, } \\
\text { from contact zone between gyttja and clay subsoil }\end{array}$ & $\begin{array}{c}\text { Early } \\
\text { Neolithic }\end{array}$ & $\begin{array}{l}\text { food- } \\
\text { crust }\end{array}$ \\
\hline Karavaikha 4 & $\begin{array}{l}2003 \text {, trench } 1 \text {, squ. } P_{21} \text {, wooden lath from concentration of laths which probably } \\
\text { represent remains of a fish trap, lying on the subsoil in the lower part oft he gyttia }\end{array}$ & $\begin{array}{l}\text { Early } \\
\text { Neolithic }\end{array}$ & wood \\
\hline Karavaikha 4 & $\begin{array}{l}2012 \text {, trench 15, squ. A19, wooden stick from lower part of gyttia almost } \\
\text { in contact zone with peaty clay subsoil }\end{array}$ & Early Neolithic & wood \\
\hline Karavaikha 4 & $\begin{array}{l}\text { 2012, trench 15, squ. JA19, fragment of wooden sculpture in middle part of gyttia } \\
\text { substantially above main level of artefacts }\end{array}$ & $\begin{array}{c}\text { Early } \\
\text { Neolithic }\end{array}$ & wood \\
\hline Karavaikha 4 & $\begin{array}{l}2012 \text {, trench } 15, \text { squ. G20, wide flat wooden stick from lower part of gyttia } \\
\text { almost in contact zone with peaty clay subsoil }\end{array}$ & $\begin{array}{c}\text { Early } \\
\text { Neolithic }\end{array}$ & wood \\
\hline Karavaikha 4 & $\begin{array}{l}2012 \text {, trench } 15, \text { squ. JA19, fragment of wooden sculpture in middle part of gyttia } \\
\text { substantially above main level of artefacts }\end{array}$ & $\begin{array}{l}\text { Early } \\
\text { Neolithic }\end{array}$ & wood \\
\hline Tudozero 5 & $\begin{array}{l}\text { 1989, squ. Go/1, }-178 \text {, depth } 190 \mathrm{~cm} \text { from ancient surface, charred wooden plank } \\
\text { from base of lower black Early Neolithic layer with pottery }\end{array}$ & $\begin{array}{l}\text { Early } \\
\text { Neolithic (?) }\end{array}$ & charcoal \\
\hline Tudozero 5 & $\begin{array}{l}\text { 1990, trench 1, squ. E1, charred organic crust from inside of comb-decorated } \\
\text { conical vessel, lower black Early Neolithic layer }\end{array}$ & $\begin{array}{c}\text { Early Neolithic } \\
\text { (earliest } \\
\text { Comb Ware) }\end{array}$ & foodcrust \\
\hline Tudozero 5 & $\begin{array}{l}\text { 2000, trench 12, squ. } A_{1},-397 \text {, depth } 340 \mathrm{~cm} \text { from ancient surface, lower grey } \\
\text { early Neolithic layer } 2 \text {, hearth }\end{array}$ & $\begin{array}{l}\text { Early } \\
\text { Neolithic }\end{array}$ & charcoal \\
\hline Tudozero 5 & $\begin{array}{l}\text { 1993, trench } 8, \text { squ. B1/2, }-258 \text {, depth } 220 \mathrm{~cm} \text { from ancient } \\
\text { surface, lower grey early Neolithic layer } 2 \text {, hearth }\end{array}$ & $\begin{array}{l}\text { Early } \\
\text { Neolithic }\end{array}$ & charcoal \\
\hline Tudozero 5 & $\begin{array}{l}\text { 1989, squ. A2, charred crust from inside of rimsherd with fish vertebra } \\
\text { impressions, lower black Early Neolithic layer }\end{array}$ & $\begin{array}{l}\text { Early Neolithic } \\
\text { (Sperrings) }\end{array}$ & foodcrust \\
\hline Tudozero 5 & $\begin{array}{l}\text { 1992, trench } 5 \text {, squ. E4, }-318 \text {, depth } 260 \mathrm{~cm} \text { from ancient surface, lower black } \\
\text { Early Neolithic layer, hearth }\end{array}$ & $\begin{array}{l}\text { Early } \\
\text { Neolithic }\end{array}$ & charcoal \\
\hline Tudozero 5 & $\begin{array}{l}\text { 1992, trench } 6 \text {, squ. B3, }-329-350 \text {, depth } 310 \mathrm{~cm} \text { from ancient surface, lower black } \\
\text { Early Neolithic layer, hearth }\end{array}$ & $\begin{array}{c}\text { Early } \\
\text { Neolithic }\end{array}$ & charcoal \\
\hline Tudozero 5 & $\begin{array}{l}\text { 1998, trench } 11, \text { squ. B/G6/7, }-328 \text {, depth } 170 \mathrm{~cm} \text { from ancient surface, lower grey } \\
\text { Early Neolithic layer } 1 \text {, hearth }\end{array}$ & $\begin{array}{l}\text { Early } \\
\text { Neolithic }\end{array}$ & charcoal \\
\hline Veksa 1 & $\begin{array}{l}\text { River bank slope, segment 9, charred organic crust from vessel with } \\
\text { pitted ornamentation, Lyalovo culture }\end{array}$ & $\begin{array}{l}\text { Early to Middle } \\
\text { Neolithic (Lyalovo) }\end{array}$ & foodcrust \\
\hline Veksa 1 & 2016, test trench, layer 7 & $\begin{array}{l}\text { Middle Neolithic } \\
\text { (Lyalovo) }\end{array}$ & charcoal \\
\hline Veksa 3 & 2000, squ. 170-I, layer 9, charcoal concentration & $\begin{array}{l}\text { Early } \\
\text { Neolithic }\end{array}$ & $\begin{array}{l}\text { soil with } \\
\text { charcoal }\end{array}$ \\
\hline Veksa 3 & 2000, squ. 167-Z, layer 9, pit & $\begin{array}{l}\text { Early } \\
\text { Neolithic }\end{array}$ & $\begin{array}{l}\text { soil with } \\
\text { charcoal }\end{array}$ \\
\hline Veksa 3 & $\begin{array}{l}\text { 2015, trench 1, squ. L-167, layer 9, charred crust from inside a sparsely } \\
\text { ornamented Early Upper Volga culture vessel (vessel no. 2015/17) }\end{array}$ & $\begin{array}{l}\text { Early Neolithic } \\
\text { (Upper Volga) }\end{array}$ & foodcrust \\
\hline Veksa 3 & 2000, squ. 171-I, layer 9, pit & $\begin{array}{l}\text { Early Neolithic } \\
\text { (Upper Volga) }\end{array}$ & $\begin{array}{l}\text { soil with } \\
\text { charcoal }\end{array}$ \\
\hline Veksa 3 & 1997, squ. 167, from charcoal-rich lens & $\begin{array}{l}\text { Early Neolithic } \\
\text { (Upper Volga) }\end{array}$ & $\begin{array}{l}\text { soil with } \\
\text { charcoal }\end{array}$ \\
\hline Veksa 3 & 2016, trench 1, squ. L-166, layer 9, removal 5, feature 509 & $\begin{array}{c}\text { Early Neolithic } \\
\text { (Upper Volga) (?) }\end{array}$ & charcoal \\
\hline Veksa 3 & $\begin{array}{l}2015 \text {, trench } 1 \text {, squ. L-167, layer } 7 \text {, feature } 42 \text {, charred crust from inside of pottery } \\
\text { vessel with comb impressed ornament (same vessel as sample MAMS-27311) }\end{array}$ & $\begin{array}{c}\text { Early Neolithic } \\
\text { ("2nd comb } \\
\text { ceramic complex"/ } \\
\text { "Northern types") }\end{array}$ & $\begin{array}{l}\text { food- } \\
\text { crust }\end{array}$ \\
\hline Veksa 3 & 2000, squ. 171-I, layer 9 & $\begin{array}{l}\text { Early Neolithic } \\
\text { (Upper Volga) }\end{array}$ & $\begin{array}{l}\text { soil from } \\
\text { charcoal- } \\
\text { rich layer }\end{array}$ \\
\hline
\end{tabular}


The Early and Middle Neolithic in NW Russia: Radiocarbon chronologies from the Sukhona and Onega regions

\begin{tabular}{|c|c|c|c|c|c|c|c|c|c|}
\hline Lab. No. & $\begin{array}{l}\text { Yield } \\
\text { (\%)* }\end{array}$ & $\% \mathrm{CJ}$ & $\% \mathrm{~N} \int$ & $\begin{array}{c}\text { atomic } \\
\mathrm{C} / \mathrm{N}\end{array}$ & $\begin{array}{l}\delta 13 C \\
(\% \circ) \int\end{array}$ & $\begin{array}{l}\delta 15 \mathrm{~N} \\
(\% \circ)\end{array}$ & $\begin{array}{l}\text { Conventional } \\
14 \mathrm{C} \text { age BP:* }\end{array}$ & $\begin{array}{l}\text { Maximum age } \\
\text { cal BC \ }(95,4 \\
\% \text { probability) }\end{array}$ & Reference \\
\hline Le-8012 & & & & & & & $6320 \pm 40$ & $5460-5210$ & Kosorukova et al. 2016 \\
\hline Le-10771 & & & & & & & $6310 \pm 40$ & $5370-5220$ & Kosorukova et al. 2016 \\
\hline AAR-1717 & & 57.2 & 3.2 & 20.9 & -26.15 & 0.89 & $6222 \pm 30$ & $5300-5077$ & Piezonka et al. 2016 \\
\hline
\end{tabular}

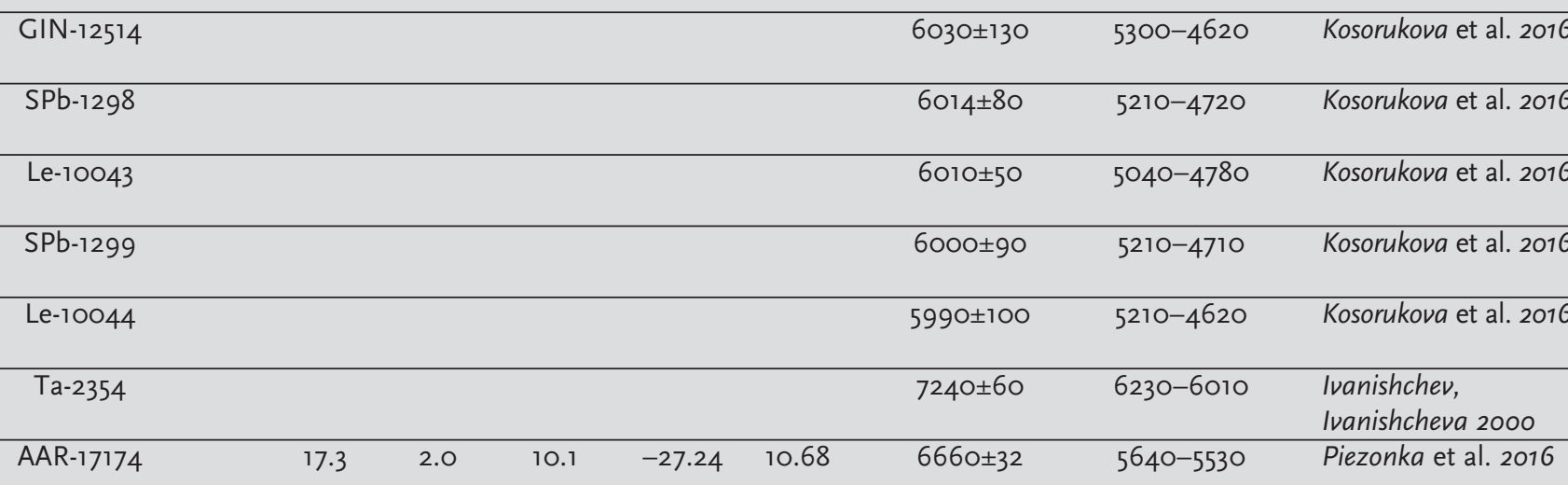

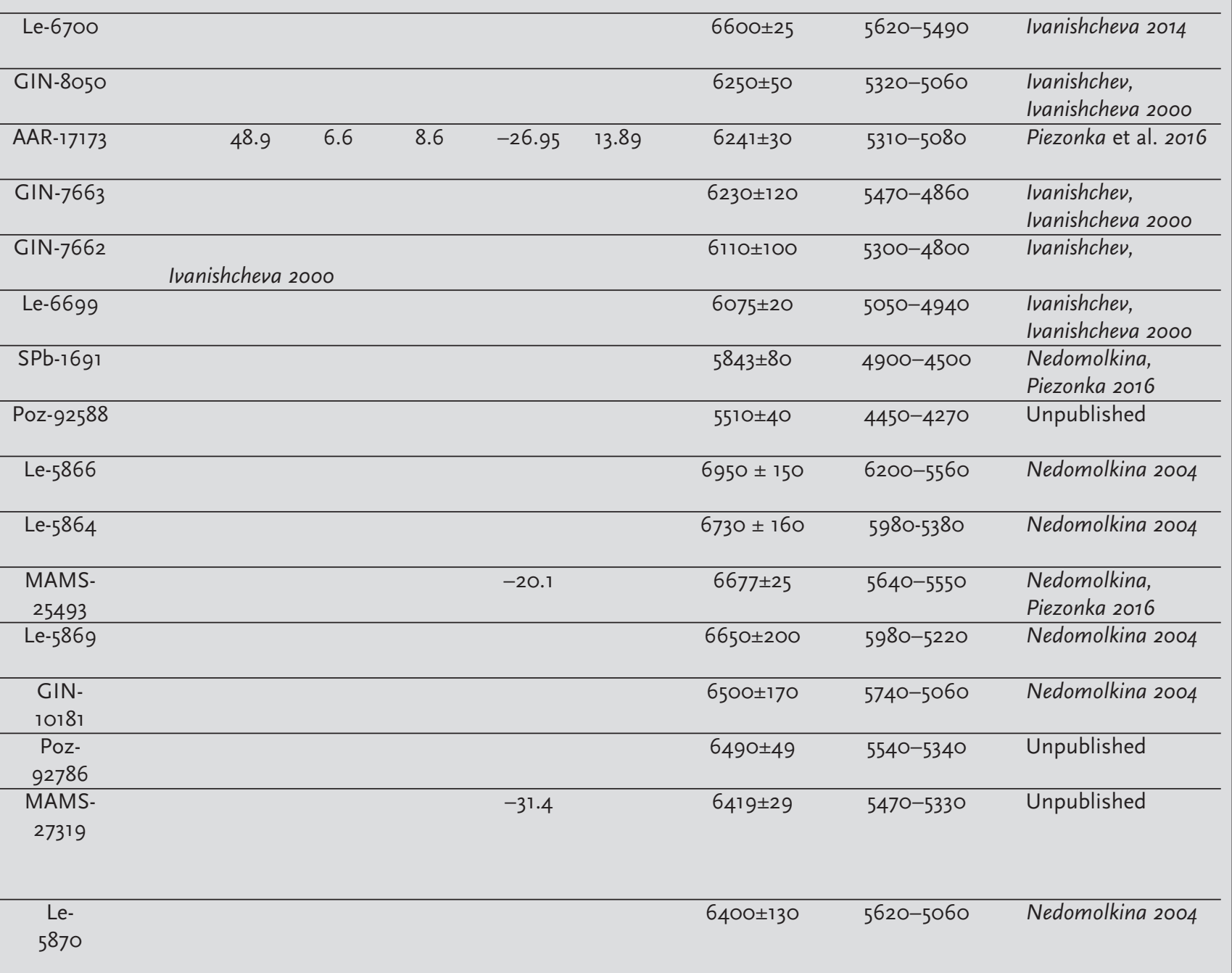




\begin{tabular}{|c|c|c|c|}
\hline Site & Context & $\begin{array}{l}\text { Chrono- } \\
\text { typological } \\
\text { association }\end{array}$ & Material \\
\hline Veksa 3 & $\begin{array}{l}\text { 1996, charred organic crust from Upper Volga pottery sherd, } \\
\text { surface find on river bank }\end{array}$ & $\begin{array}{l}\text { Early Neolithic } \\
\text { (Upper Volga) }\end{array}$ & foodcrust \\
\hline Veksa 3 & 2002, layer 9, pit & $\begin{array}{l}\text { Early } \\
\text { Neolithic }\end{array}$ & $\begin{array}{l}\text { organically } \\
\text { enriched soil }\end{array}$ \\
\hline Veksa 3 & $\begin{array}{l}\text { Surface find on river bank, charred organic crust from } \\
\text { Upper Volga pottery sherd }\end{array}$ & $\begin{array}{l}\text { Early Neolithic (earliest } \\
\text { Comb-Pitted ware) }\end{array}$ & foodcrust \\
\hline Veksa 3 & 2015, trench 1, squ. L-168, layer 9, feature 446 & $\begin{array}{l}\text { Early Neolithic } \\
\text { (Upper Volga) }\end{array}$ & charcoal \\
\hline Veksa 3 & $\begin{array}{l}\text { 1996, surface find on river bank, charred organic crust from } \\
\text { pottery sherd of the " } 2 \text { nd comb ware complex" }\end{array}$ & $\begin{array}{l}\text { Early Neolithic ("2nd } \\
\text { comb ceramic complex") }\end{array}$ & foodcrust \\
\hline Veksa 3 & 2015, trench 1, squ. L-166, layer 9, removal 1 & $\begin{array}{l}\text { Early Neolithic } \\
\text { (Upper Volga) }\end{array}$ & charcoal \\
\hline Veksa 3 & $\begin{array}{l}2015, \text { trench 1, squ. L-166, layer 9, removal 1, feature } 446, \\
\text { charred seeds of Nuphar lutea }\end{array}$ & $\begin{array}{l}\text { Early Neolithic } \\
\text { (Upper Volga) }\end{array}$ & $\begin{array}{l}\text { charred } \\
\text { seeds }\end{array}$ \\
\hline Veksa 3 & $\begin{array}{l}2015 \text {, trench 1, squ. L-167, layer } 7 \text {, feature } 42 \text {, charred crust from } \\
\text { inside of pottery vessel with comb impressed ornament (same } \\
\text { vessel as sample MAMS-27319) }\end{array}$ & $\begin{array}{l}\text { Early Neolithic ("2nd comb } \\
\text { ceramic complex"/ } \\
\text { "Northern types") }\end{array}$ & $\begin{array}{l}\text { food- } \\
\text { crust }\end{array}$ \\
\hline Veksa 3 & 2016, trench 1, squ. L-166, layer 9, removal 3 & $\begin{array}{l}\text { Early Neolithic } \\
\text { (Upper Volga) }\end{array}$ & charcoal \\
\hline Veksa 3 & 2000, squ. 168-I, layer 8, hearth & $\begin{array}{l}\text { Early Neolithic ("2nd comb } \\
\text { ceramic complex") }\end{array}$ & $\begin{array}{l}\text { soil from } \\
\text { hearth }\end{array}$ \\
\hline Veksa 3 & 2000, squ. 169-I, layer 8 & $\begin{array}{l}\text { Early Neolithic ("2nd comb } \\
\text { ceramic complex") }\end{array}$ & $\begin{array}{l}\text { soil with } \\
\text { charcoal }\end{array}$ \\
\hline Veksa 3 & $\begin{array}{l}\text { 1996, surface find on river bank, charred organic crust from } \\
\text { pottery sherd of the "2nd comb ware complex" }\end{array}$ & $\begin{array}{l}\text { Early Neolithic ("2nd comb } \\
\text { ceramic complex") }\end{array}$ & foodcrust \\
\hline Veksa 3 & $\begin{array}{l}2015 \text {, trench } 1 \text {, squ. L-168, layer } 7 \text {, feature } 43 \text {, charred seeds } \\
\text { of Polygonum lapathifol. }\end{array}$ & $\begin{array}{l}\text { arly Neolithic ("2nd comb ceramic } \\
\text { complex" / "Northern types") }\end{array}$ & $\begin{array}{c}\text { charred } \\
\text { seeds }\end{array}$ \\
\hline Veksa 3 & 2015 , trench 1, squ. L-168, layer 9, feature 446 & $\begin{array}{l}\text { Early Neolithic } \\
\text { (Upper Volga) }\end{array}$ & charcoal \\
\hline Veksa 3 & $\begin{array}{l}2015 \text {, trench 1, squ. L-166, layer 9, removal 1, feature } 446 \text {, } \\
\text { charred seeds of Polygonum lapathifol. }\end{array}$ & $\begin{array}{l}\text { Early Neolithic } \\
\text { (Upper Volga) }\end{array}$ & $\begin{array}{l}\text { charred } \\
\text { seeds }\end{array}$ \\
\hline Veksa 3 & $\begin{array}{l}\text { 1996, surface find on river bank, charred organic crust from } \\
\text { pottery sherd of the "Northern types" }\end{array}$ & $\begin{array}{l}\text { Late Early Neolithic } \\
\text { ("Northern types") }\end{array}$ & $\begin{array}{l}\text { food- } \\
\text { crust }\end{array}$ \\
\hline Veksa 3 & $\begin{array}{l}2015 \text {, trench } 1 \text {, squ. L- } 168 \text {, layer } 9 \text {, feature } 446 \text {, charred crust } \\
\text { from inside of potsherd }\end{array}$ & $\begin{array}{l}\text { Early Neolithic } \\
\text { (Upper Volga) }\end{array}$ & $\begin{array}{l}\text { food- } \\
\text { crust }\end{array}$ \\
\hline Veksa 3 & 2015, trench 1, squ. L-166, layer 8, removal 4 & $\begin{array}{l}\text { Early Neolithic ("2nd comb } \\
\text { ceramic complex") }\end{array}$ & charcoal \\
\hline Veksa 3 & 2015, trench 1, squ. L-167, layer 7 & $\begin{array}{l}\text { arly Neolithic ("2nd comb ceramic } \\
\text { complex" / "Northern types") }\end{array}$ & charcoal \\
\hline Veksa 3 & $\begin{array}{l}2015 \text {, trench 1, squ. L-167, layer } 7 \text {, feature } 42 \text {, charcoal adhering Ea } \\
\text { to vessel from which stem samples MAMS-27311 and MAMS-27319 }\end{array}$ & $\begin{array}{l}\text { arly Neolithic ("2nd comb ceramic } \\
\text { complex" / "Northern types") }\end{array}$ & charcoal \\
\hline Veksa 3 & 2015, trench 1, squ. L-168, layer 7, feature 43 & $\begin{array}{l}\text { arly Neolithic ("2nd comb ceramic } \\
\text { complex" / "Northern types") }\end{array}$ & charcoal \\
\hline Veksa 3 & 2000, squ. 168-I, layer 6 & $\begin{array}{l}\text { Late Early Neolithic } \\
\text { (“Northern types") }\end{array}$ & $\begin{array}{l}\text { soil with } \\
\text { charcoal }\end{array}$ \\
\hline Veksa 3 & 1997, squ. 166-I, layer 6 & $\begin{array}{l}\text { Late Early Neolithic } \\
\text { ("Northern types") }\end{array}$ & charcoal \\
\hline Veksa 3 & $\begin{array}{l}\text { 1996, shore segment } 6 \text {, surface find on river bank, charred organic } \\
\text { crust from Narva type pottery vessel (same vessel as KIA-33926) }\end{array}$ & $\begin{array}{l}\text { Middle Neolithic } \\
\text { (Narva) }\end{array}$ & $\begin{array}{c}\text { foodcrust } \\
\text { (outer surface) }\end{array}$ \\
\hline Veksa 3 & $\begin{array}{l}\text { 1996, shore segment } 6 \text {, surface find on river bank, charred organic } \\
\text { crust from Narva type pottery vessel (same vessel as KIA-49796) }\end{array}$ & $\begin{array}{l}\text { Middle Neolithic } \\
\text { (Narva) }\end{array}$ & $\begin{array}{c}\text { foodcrust } \\
\text { (inner surface) }\end{array}$ \\
\hline Veksa 3 & $1997,170-I$, layer 5 & $\begin{array}{c}\text { Middle Neolithic } \\
\text { (Kargopol') }\end{array}$ & $\begin{array}{l}\text { soil with } \\
\text { charcoal }\end{array}$ \\
\hline
\end{tabular}

$\int$ EA-IRMS measurements from School of Life Sciences, University of Bradford, England (Veksa 3 ) and AMS ${ }^{14 C}$ Dating Centre at Aarhus University (Karavaikha, Tudozero). Italics: isotope determination in the course of AMS dating.

* Measurements from the Leibniz Labor for AMS Dating and Stable Isotope Research, Christian Albrechts University, Kiel, Germany. 
The Early and Middle Neolithic in NW Russia: Radiocarbon chronologies from the Sukhona and Onega regions

\begin{tabular}{|c|c|c|c|c|c|c|c|c|c|}
\hline Lab. No. & $\begin{array}{l}\text { Yield } \\
\text { (\%)* }\end{array}$ & $\%$ CJ & $\% \mathrm{Ng}$ & $\begin{array}{l}\text { atomic } \\
\mathrm{C} / \mathrm{N}\end{array}$ & $\begin{array}{l}\delta 13 C \\
(\% \circ) \int\end{array}$ & $\begin{array}{l}\delta 15 N \\
(\% \circ) \int\end{array}$ & $\begin{array}{l}\text { Conventional } \\
14 \mathrm{C} \text { age } \mathrm{BP}:\end{array}$ & $\begin{array}{l}\text { Maximum age } \\
\text { cal BC ๆ }(95,4 \\
\% \text { probability) }\end{array}$ & Reference \\
\hline $\begin{array}{c}\text { KIA- } \\
49797\end{array}$ & 68 & 60.3 & 4.0 & 17.5 & -27.38 & 8.05 & $6386 \pm 21$ & $5470-5320$ & Piezonka 2015 \\
\hline $\begin{array}{c}\text { KIA- } \\
33929 \\
\end{array}$ & 18 & $62 *$ & & & -24.3 & & $6340 \pm 30$ & $5460-5220$ & Piezonka 2008 \\
\hline $\begin{array}{l}\text { KIA- } \\
49798\end{array}$ & 62 & 51.4 & 5.0 & 12.1 & -27.76 & 6.31 & $6314 \pm 22$ & $5340-5220$ & Piezonka 2015 \\
\hline $\begin{array}{l}\text { MAMS- } \\
27322 \\
\end{array}$ & & 13.4 & & & -27.2 & & $6290 \pm 27$ & $5320-5220$ & Unpublished \\
\hline $\begin{array}{c}\text { KIA- } \\
49799\end{array}$ & 62 & 54.1 & 54.1 & 7.7 & -28.10 & 9.42 & $6285 \pm 30$ & $5320-5220$ & Piezonka 2015 \\
\hline $\begin{array}{l}\text { MAMS- } \\
27321\end{array}$ & & 30.6 & & & -23.3 & & $6273 \pm 28$ & $5310-5220$ & Unpublished \\
\hline $\begin{array}{c}\text { Poz- } \\
84485\end{array}$ & & & & & & & $6240 \pm 40$ & $5310-5070$ & Unpublished \\
\hline $\begin{array}{c}\text { MAMS- } \\
27311\end{array}$ & & & & & -24.5 & & $6236 \pm 34$ & $5310-5070$ & Unpublished \\
\hline $\begin{array}{l}\text { Poz- } \\
92774\end{array}$ & & & & & & & $6230 \pm 40$ & $5310-5060$ & Unpublished \\
\hline $\begin{array}{c}\text { Le- } \\
5868\end{array}$ & & & & & & & $6220 \pm 150$ & $5480-4810$ & Nedomolkina 2004 \\
\hline $\begin{array}{c}\text { Le- } \\
5856\end{array}$ & & & & & & & $6200 \pm 170$ & $5480-4730$ & Nedomolkina 2004 \\
\hline $\begin{array}{c}\text { KIA- } \\
33927\end{array}$ & 71 & 53.4 & 8.7 & 7.2 & -29.34 & 10.27 & $6185 \pm 30$ & $5220-5040$ & Piezonka 2008 \\
\hline $\begin{array}{l}\text { Poz- } \\
92587\end{array}$ & & & & & & & $6170 \pm 40$ & $5220-5000$ & Unpublished \\
\hline $\begin{array}{c}\text { MAMS- } \\
27313\end{array}$ & & & & & -23.9 & & $6126 \pm 32$ & $5210-4980$ & Unpublished \\
\hline $\begin{array}{c}\text { Poz- } \\
84485\end{array}$ & & & & & & & $6110 \pm 40$ & $5210-4940$ & Unpublished \\
\hline $\begin{array}{c}\text { KIA- } \\
33928\end{array}$ & 61 & 56.3 & 4.7 & 14.1 & -30.88 & 10.33 & $6105 \pm 30$ & $5210-4940$ & Piezonka 2008 \\
\hline $\begin{array}{l}\text { MAMS- } \\
27312\end{array}$ & & & & & -24.7 & & $6068 \pm 33$ & $5190-4850$ & Unpublished \\
\hline $\begin{array}{l}\text { MAMS- } \\
27320\end{array}$ & & & & & -28.4 & & $6059 \pm 29$ & $5050-4850$ & Unpublished \\
\hline $\begin{array}{l}\text { MAMS- } \\
27317 \\
\end{array}$ & & & & & -21.3 & & $5957 \pm 26$ & $4930-4770$ & Unpublished \\
\hline $\begin{array}{c}\text { MAMS- } \\
27310\end{array}$ & & & & & $-25 \cdot 5$ & & $5928 \pm 35$ & $4900-4720$ & Unpublished \\
\hline $\begin{array}{l}\text { MAMS- } \\
27318 \\
\end{array}$ & & & & & -23.8 & & $5898 \pm 26$ & $4830-4710$ & Unpublished \\
\hline $\begin{array}{c}\text { Le- } \\
5857\end{array}$ & & & & & & & $5700 \pm 700$ & $6100-3010$ & Nedomolkina 2004 \\
\hline $\begin{array}{l}\text { GIN- } \\
10182\end{array}$ & & & & & & & $5650 \pm 150$ & $4900-4080$ & Nedomolkina 2004 \\
\hline $\begin{array}{c}\text { KIA- } \\
49796 \\
\end{array}$ & 52 & 56.3 & 9.4 & 7.0 & -28.54 & 11.87 & $5492 \pm 23$ & $4440-4270$ & Piezonka 2015 \\
\hline $\begin{array}{c}\mathrm{KIA-} \\
33926\end{array}$ & 61 & 48.8 & 9.2 & 6.2 & -30.51 & 12.66 & $5425 \pm 30$ & $4340-4240$ & Piezonka 2008 \\
\hline $\begin{array}{l}\text { GIN- } \\
10180\end{array}$ & & & & & & & $5220 \pm 320$ & $4800-3350$ & Nedomolkina 2004 \\
\hline
\end{tabular}

9 The results have been calibrated using OxCal v4.2.4 (Bronk Ramsey 2009) and the IntCal13 (Reimer et al. 2013) calibration data, with date ranges rounded outwards to the nearest 10 years. The carbonized surface residue cannot be older than this date range. If the ${ }^{14 C}$ age is subject to a freshwater reservoir effect, the true date of the carbonized surface residue could be significantly more recent. 